\title{
The Influence of Bali Brand Equity on Tourists Traveling Behavior
}

\author{
I Ketut Surya Diarta
}

\author{
School of Postgraduate Study \\ Doctorate Degree in Tourism Udayana University
}

Coressponding author: suryadiarta_unud@yahoo.com

\section{ARTICLE INFO}

Received

16 March 2015

Accepted

20 August 2015

Available online

07 September 2015

\begin{abstract}
There is already known that brand equity of tourism destination can influence tourist decision making to choose a destination to be visited. However, there is no information on how tourism destination brand equity influences tourist's behavior during their vacation in destination such as extend tourist length of stay, encourage to be revisit tourist, and willing to recommend for others. This research aims to analyze the effect of Bali brand equity on tourists traveling behavior. The research was conducted from January to November 2015 in five main tourism objects in Bali. Data were collected through survey of 240 foreign tourists and analyzed using multivariate analysis of variance (MANOVA). The research result shows that the influence of Bali brand equity to tourists traveling behavior as a whole through destination brand awareness, destination brand image, destination brand association, and destination perceived quality. While, individually: (a) the frequency of visiting Bali is affected by distinctive features for stunning natural beauty of Bali and safe and peaceful Bali tourism destination, (b) the length of stay during vacation in Bali is affected Bali as one of the world's main destination, strong brand Bali recall, warm-politely-friendly local people, safe and peaceful destination, and excellent tourism physical facilities, and (c) the frequency recommending Bali to others is affected by distinctive features for stunning natural beauty of Bali, warm-politelyfriendly local people, and safe and peaceful destination. Give stressing on the attributes of destination that develop tourist's positive behavior to Bali as a tourism destination will determine the success of Bali in world tourism market competition.
\end{abstract}

Keywords: destination, brand, equity, Bali, behavior

\section{Introduction}

\section{Background}

Importance of tourism to the world economy is reflected in the UNWTO key trends and outlook international tourism in 2014 (World Tourism Organization, 2005) that tourism as one of the keys to the development of the world, creating prosperity and welfare. This is motivated by some empirical data on the contribution of world tourism in 2014, where tourism contributes for $9 \%$ of world
GDP, creates one among the 11 types of existing jobs, creating export value of USD 1.5 trillion, which is equivalent to $6 \%$ of world exports and $29 \%$ of all exports in the services sector (World Tourism Organization, 2005).

One of the important data about the distribution of world tourism is the number of tourist arrivals is not evenly distributed in each country and continent. The world's top ten tourism destinations have almost 50 percent of the total world international tourist arrival. The remaining contested by all countries in the 
world that develop tourism industry as one effort to push its economy. This means, tourism destinations have a very strong competition to gain tourists in world tourists market (Chang, 2008).

The importance of tourism destinations brand development to increase international tourist's arrival which affected the increase in foreign exchange has been recognized by some countries. One empirical example is New Zealand brand "100\% Pure New Zealand" in 1999 was able to double the revenue from foreign tourists exceeded 3 billion dollars New Zealand in 2005.

Anchored in the context of tourism destination marketing, the brand must have a high equity to attract tourists. Chang (2008) adds that the purpose of brand equity in tourism is "maximizing the uniqueness of destinations to distinguish it from other destinations in reaching the target market". Destination brand equity itself is essentially to optimize the uniqueness of the destination as a differentiator to other destinations in reaching the target market. More specifically, brand equity "incites beliefs, evoke emotions and prompt behaviors" (Kotler and Gertner, 2002 in Chang, 2008). The number of tourism destinations with each uniqueness and advantages make the more competitive tourism industry. According to Lee and Leh (2011) knowing destination's brand equity is very important to support destination marketing strategy. The high brand equity of a destination will influence the behavior of foreign tourists before, during, and after having vacation in tourism destination.

Bali, as one of the tourism destination in the world, is also has a brand equity that influences international tourists to choose Bali as their tourism destination. International tourists visit Bali as a tourism destination, in part, due to the high-value brand equity of Bali as tourism destination. On one hand, there is already known that the brand equity of tourism destination influences tourist decision making to choose a destination to be visited. On the other hand, there is no information on how the brand equity of tourism destinations in influencing the tourists behavior during their vacation in destination. For example, how brand equity of Bali attracts tourists to extend their length of stay, to encourage tourists to be repeater guests (revisit tourists), as well as to grow tourists willingness to recommend Bali as tourism destinations for family, friends or others.

Based on the background above, the research on the effect of Bali brand equity as a tourism destination on tourists traveling behavior gets a strong foothold to be conducted. It is also justified by the fact that there is unavailability of data on what variables of brand equity of Bali as a tourism destination that significantly affects the behavior of foreign tourists in destination.

\section{Research Purpose}

This research aims to analyze the effect of Bali brand equity on tourists traveling behavior.

\section{Literature Review}

\section{Understanding consumer behavior}

Consumer behavior according Swarbrooke and Susan (2007) is "a process that involves individual and group activities when selecting, buying, using, or leaving a product, service, idea, or experience to satisfy the needs and desires of consumers". Furthermore Hoffman and Bateson (2010) states that consumer behavior has at least three properties, namely:

a. Consumer behavior is dynamic in which a consumer, consumer groups, and the community has changed over time. Consequently, the generalization of consumer behavior is usually limited to a certain period, products, and individuals or groups.

b. In order to understand the customer and develop appropriate marketing strategies, we need to understand what they think, feel, do, and what affects consumer thought and feeling.

c. There are exchange between individuals that is consistent with the definition of marketing that emphasizes the importance of the exchange. In fact, the role of marketing is to create exchanges with consumers through the formulation and implementation of marketing strategies. 
When we want to optimize the effectiveness and efficiency of marketing then we must seek to understand how consumers make decisions to buy or select or use a tourism product. Associated with tourism, understanding tourist behavior allows us to intervene in any part of marketing strategy that is considered necessary in order to achieve the goals that have been set (Swarbrooke and Susan, 2007). Furthermore, understanding the tourist behavior is useful in the development of tourism products and services in order to meet the expectations of tourists.

\section{The tourist planned decision making process in traveling}

Tourist behavior has become essential in tourism destination marketing strategy. Select, purchase, and consume tourism products including tourism destination involves a set of psychological processes and environmental influences that must be considered (Kozak and Decrop, 2009). Generally, according to Kozak and Decrop (2009) decision-making process as tourists' behavior in traveling can be classified into three stages: pre purchase, consuming, and post consuming.

1. Pre-purchase stage

This stage is characterized by potential travelers that have the motivation, needs, and wants to take a vacation to certain destination. They try to find various tourism destination information and evaluate the various alternatives available to select one of the most suitable destinations based on some criteria.

2. Consuming stage

This phase tourists enjoy travel in destinations and consume products and services provided. This phase consists of series of events and activities that help travelers sense, connect, and express their symbolic value into choices and activities performed during the vacation. Traveler experiences at destinations are very subjective and are created because of sensations, emotions, and social interactions that lead to learning and understanding of the real situation in the destination.

3. Post consuming stage

After traveled to destination then the traveler evaluates his experience with the information obtained from various sources with their own real experiences in destination. The evaluation results is usually a feeling of satisfaction or dissatisfaction that led to the decision or desire to re-visit or divert to other destinations. Other result is usually recommendation or no recommendation to friends or family based on his experience (Kozak and Decrop, 2009).

\section{The effect of Tourism Destination Brand Equity on Travelling Behavior}

Related to traveling behavior of tourists based on consumer behavior theory as stated by Konecnik and Gartner ()2007 and Chen and Tseng (2010) that the traveler's behavior in the context of brand equity reflected in destination brand loyalty which is reflected in at least three indicators, namely: (1) the frequency of visiting destinations, (2) the length of stay in destination, and (3) the frequency of recommending destinations to others. Aspects of these behaviors are influenced by perceptional aspects, namely cognitive level (destination brand awareness) and affective level (destination brand image, destination brand association, and destination brand perceived quality).

According to Aaker (in Chang, 2008) brand equity is defined as "a set of brand assets and liabilities linked to a brand, its name and symbol". Then, Ming, Ismail and Rasiah (2011) define brand equity as "the incremental utility and value added to a product by its brand name". Thus, brand equity lies on how much asset or added value owned by a related product names and symbols attached to it. The application of Consumer Based Brand Equity specifically for tourism destinations was introduced by Konečnik (2005), followed by the subsequent publications by Konecnik and Gartner (2007) and Konecnik Ruzzier (2013), a tourism destination brand built by: (a) destination awareness, (b) destination image, (c) perceived quality, and (d) destination loyalty. Richie and Richi (in Jalilvand, Esfahani and Samiei, 2010) stated that brand equity should be able to be taken into consideration and persuade tourist to travel to the destination.

http://ojs.unud.ac.id/index.php/eot 
Aaker (in Ming, Ismail and Rasiah, 2011) stressed that the destination brand awareness is the beginning of the emergence of brand loyalty on a tourism destination. If tourists have the awareness of the brand destination then it is likely they have a certain image about the tourism destination concerned. Consequently, the positive image on the brand destinations will increase the possibility of traveling to Bali, repeating visit to Bali, or extending their length of stay in Bali and if they are satisfy they will recommend the destination to others.

Destination brand image is an important factor in building tourist trust to the destination. Ming, Ismail and Rasiah (2011) states that there are direct and indirect impacts of the destination brand image to the tourist trust level and affect the next decision in the future. Travelers who have a good image of a tourist destination then it is likely to have a positive influence to the destination, raises his loyalty to the destinations and eventually return back as a repeater guest, increase the length of stay in destinations, and most likely recommend that destination to others.

Destination brand association is any mental relationships associated with a tourism destination that may involve attributes of products or services in a destination that relate either directly or indirectly with tourists (Tuominen, 1999). Destination brand association also affect whether or not traveler has a comfort feeling during vacation in destination. Traveler who has a strong association with destination tends to be longer stay in destination. If they are satisfied, therefore, they would recommend the destination to others.

The quality of products according to Parasuraman et al. (in Suh and Pedersen, 2010) has an effect on choosing product behavior. According to Chiou et al. (in Suh and Pedersen, 2010) in the context of tourism, the destination quality perceived by tourist generates conative response on the respective destination. This determines the conative response which resulted in the purchase of products offered by a destination and the loyalty of tourists to destinations for instance to be a repeater guest and stay longer in the destination as well as the willingness to recommend the destination to others. Studies Gil et al. (in Suh and Pedersen, 2010) showed that the higher the quality of a tourist destination perceived by tourists then the stronger possibility travelers behave positively towards that destination.

\section{Methodology}

The survey of 240 foreign tourists (Appendix 1) as respondents carried out from January 2015 until November 2015 in five main tourism objects in Bali namely: Tanah Lot (107 respondents), Ulun Danu Beratan (44 respondents), Uluwatu (43 respondents), Penelokan Batur (28 respondents), and Taman Ayun (18 respondents). Criteria for respondents are: (a) overnight tourists but not as transit travelers, (b) visited at least one of the five major tourist attractions that is used as research location, (c) already have psychological evaluation and perception on tourism objects visited, (d) respondents are willing to, capable for and comfortable in providing information needed to answer the research objectives. This research uses a quantitative research design. Data were analyzed using multivariate analysis of variance (MANOVA) with SPSS 16.0 for Windows software (Santoso, 2014).

Brand equity of Bali as a tourism destination is measured using five main variables measurement, namely: (a) destination brand awareness, (b) destination brand image, (c) destination brand association, (d) destination brand percieved quality, and (e) destination brand loyalty (Jamal and Naser, 2002; Konečnik, 2005; Konecnik and Gartner, 2007; Türkyılmaz and Özkan, 2007; Chen and Tseng, 2010; Konecnik Ruzzier, 2013). While, tourists traveling behavior is measured using three variables, namely: (a) the frequency of visited Bali (times), (b) length of stay during vacation in Bali (days), (c) the frequency recommending Bali to others (times).

General model for MANOVA analysis used in this research (Santoso, 2014) is:

$Y_{1}+Y_{2}+Y_{3}=f\left(X_{1}+X_{2}+\ldots+X_{n}\right)$ 
in which:

$Y_{1}=$ the frequency of visiting Bali (times)

$\mathrm{Y}_{2}=$ length of stay during vacation in Bali (days),

$\mathrm{Y}_{3}=$ the frequency recommending Bali to others (times).

$X_{1}, X_{2}, \ldots, X_{n}=$ brand equity of Bali parameters

Destination brand awareness consists of 7 parameters (X1 to X7) and three hypotheses:

- Hypothesis (1a): destination brand awareness significantly affect the frequency of tourist arrivals to Bali

- Hypothesis (1b): destination brand awareness significantly affect the length of stay during the vacation in Bali

- Hypothesis (1c): destination brand awareness significantly affect the frequency of recommending Bali tourism destinations to others

Destination brand image consists of 9 parameters (X8 to X16) and three hypotheses:

- Hypothesis (2a): destination brand image significantly affect the frequency of tourist arrivals to Bali

- Hypothesis (2b): destination brand image affect the length of stay during the vacation in Bali

- Hypothesis (2c): destination brand image significantly affect the frequency of recommending Bali tourism destinations to others

Destination brand association consists of 10 parameters (X17 to X26) and three hypotheses:

- Hypothesis (3a): destination brand association significantly affect the frequency of tourist arrivals to Bali

- Hypothesis (3b): destination brand association affect the length of stay during the vacation in Bali

- Hypothesis (3c): destination brand association significantly affect the frequency of recommending Bali tourism destinations to others

Destination brand perceived quality consists of 11 parameters (X27 to X37) and three hypotheses:
- Hypothesis (4a): destination perceived quality significantly affect the frequency of tourist arrivals to Bali

- Hypothesis (4b): destination perceived quality affect the length of stay during the vacation in Bali

- Hypothesis (4c): destination perceived quality significantly affect the frequency of recommending Bali tourism destinations to others

For all hypotheses, decion-making criterion is:

- If number of sig. $>0,05$ then $\mathrm{H}_{0}$ is accepted

- If number of sig. $<0,05$ then $\mathrm{H}_{0}$ is rejected

Before performing factor analysis, first the research instruments were tested concerning the reliability and validity of the questionnaire. Based on the research instrument reliability test was obtained Cronbach's Alpha of 0.917> 0.60 (reliable) as can be seen on Appendix 2. Furthermore, test of research instrument validity was obtained Corrected Item-Total Correlation $>\mathrm{r}$ table $(0.11)$ (valid) as can be seen on Appendix 3 (Santoso, 2014).

\section{Results and Discussion}

\section{Respondent Characteristics}

Of the 240 respondents, $42.50 \%$ were male and $57.5 \%$ female, a difference of $15.0 \%$. The average age of respondents was 40.09 years with a range between 18 years old to 81 year old. A total of 76.67 percent of respondents visit Bali as their first destination in this traveling time prior to other destinations in the world. While, the remaining 23.33 percent visited Bali after other destinations, both destinations in Indonesia and abroad.

The average frequency of visiting Bali was 5.48 times. The number of respondents who has his first traveling to Bali is 39.2 percent while the remaining 60.8 percent are repeater guests. The average length of stay in Bali is 18.08 days and the average frequency of recommending Bali tourism destinations as a travel destination to others is 7.33 times. 
Related to travel arrangements to Bali, 83.4 percent of respondents do personal travel arrangements while the remaining 16.7 percent arranged by travel agents. As many as 25.8 percent of respondents travel to Bali alone, 50.0 percent was accompanied by family members, and 24.2 percent travel in the group.

\section{Effect of destination brand awareness on foreign tourists traveling behavior}

Based on the MANOVA analysis, there are two test results: (a) between groups (multivariate tests) and (b) individually (test of between-subjects effects) (Santoso, 2014) as can see in Table 1, Appendix 4, and Appendix 5.

Tabel 1. Multivariate Tests and Test of Between-Subjects Effects Destination Brand Awareness
Bali, and the frequency recommending Bali to others) (sig. Roy's Largest Root <0.05).

Parameter $\mathrm{X} 3$ is part of brand recognition indicator while parameter X5 is derived from brand recall indicators. Brand tourism destination is usually raised in the minds of travelers (recognition process) and stimulates them to consider choosing a particular tourism destination to be chosen (Percy and Rossiter, 1992). When tourists will travel to Europe, Asia, or America then in their mind already has certain brand recognition to those destinations. If a destination does not have particularly a well-known brand then this process will be skipped and the certain tourism destination is escaped from tourists' attention. Bali, as a brand of tourism destination, has an advantage in this case because its brand recognition is very high in the world. This causes both X3 and X5 influencing significantly the behavior of travelers during

\begin{tabular}{|c|c|c|c|c|c|}
\hline \multirow[t]{2}{*}{ No } & \multirow{2}{*}{$\begin{array}{l}\text { Destination } \\
\text { Brand } \\
\text { awareness } \\
\text { parameters }\end{array}$} & Multivariate & \multicolumn{3}{|c|}{ Test of Between-Subjects Effe } \\
\hline & & $\begin{array}{l}\text { Sig. Roy's } \\
\text { Largest Root }\end{array}$ & $\begin{array}{l}\text { Sig. Y1 } \\
\text { (Hypothesis } \\
\text { 1a) }\end{array}$ & $\begin{array}{l}\text { Sig. Y2 } \\
\text { (Hypothesis } \\
\text { 1b) }\end{array}$ & $\begin{array}{l}\text { Sig. } \\
\text { (Hy1 } \\
1 \mathrm{c})\end{array}$ \\
\hline 1 & $\begin{array}{l}\text { X3 } \\
\text { Bali as one } \\
\text { of the } \\
\text { world's } \\
\text { main } \\
\text { destination }\end{array}$ & $\begin{array}{l}.010 \\
\text { (significantly } \\
\text { affects) }\end{array}$ & .444 & $\begin{array}{l}.034 \\
\text { (significantly } \\
\text { affects) }\end{array}$ & .110 \\
\hline 2 & $\begin{array}{l}\text { X5 } \\
\text { Strong } \\
\text { brand Bali } \\
\text { recall }\end{array}$ & $\begin{array}{l}.020 \\
\text { (significantly } \\
\text { affects) }\end{array}$ & .908 & $\begin{array}{l}.041 \\
\text { (significantly } \\
\text { affects) }\end{array}$ & .759 \\
\hline 3 & $\begin{array}{l}\text { X2 } \\
\text { Familiarity } \\
\text { of brand } \\
\text { Bali }\end{array}$ & .688 & .573 & .700 & .860 \\
\hline
\end{tabular}

$\mathrm{Y}_{1}=$ the frequency of visiting Bali (times)

$\mathrm{Y}_{2}=$ length of stay during vacation in Bali (days)

$\mathrm{Y}_{3}=$ the frequency recommending Bali to others (times).

Source: Appendix 4 and 5

\section{a. Multivariate test}

Between group, simultaneously parameter X3 and X5 (Bali as one of the world's main destination and strong brand Bali recall) significantly affect all together tourists traveling behavior simultaneously (Y1, Y2, Y3: the frequency of visited Bali, length of stay during in Bali length of stay during in

\section{b. Test of Between-Subjects Effects}

Individually, only two parameter measurements (X3 and X5) significantly effect on tourism traveling behavior. Firstly, X3 (Bali as one of the world's main destination) 
significantly effect on Y2 (length of stay during in Bali) with sig. $0.034<0.05$. Secondly, X5 (strong brand Bali recall) also significantly effect on Y2 (length of stay during in Bali) with sig. $0.041<0.05$. Based on the analysis, only hypotheses $1 \mathrm{~b}$ (destination brand awareness significantly affects the length of stay during the vacation in Bali) can be proven in this regard.

This indicates that Bali as a world tourism destination brand has succeeded in making the tourists stay longer in Bali or make tourists want to extend their vacation time to enjoy the Bali compared to move on other tourism destinations. But, there is not enough significant evidence to say that the $\mathrm{X} 3$ parameter influents to other tourist traveling behaviors such as increasing the frequency of visiting Bali or recommending Bali to others. The same thing happened on the parameters X5 (strong brand Bali recall) were only able to significantly influence the behavior of Y2 (length of stay during in Bali) but not against Y1 or Y3. In summary, destination brand awareness only affects the length of stay of tourist during vacation in Bali.

Parameters X3 and X5 are the parameters of the destination brand awareness factor. According to Keller (1993), destination brand awareness is very important in potential tourist's decision-making process to visit certain destination, namely:

a. As a tourism destination brand name appears in the minds of potential tourists they associate it with a destination to be visited. Consequently, if the brand destinations awareness is high enough to be put in the minds of travelers, it is likely influencing the decision-making process to select certain tourist destinations compares to the unknown destination. Here, the role of parameter X3 and X5 are very important.

b. Destination brand awareness influence tourist's decision making as one of the consideration in destination choice judgment. Several studies Keller (1993) show that the minimum level of brand awareness is sometimes enough to have a significant effect on the trips to destination especially when tourists do not have any else information or have never traveled to the destination before. The results of the analysis support this assumption that the role parameter $\mathrm{X} 3$ or $\mathrm{X} 5$ significantly individually influences to the $\mathrm{Y} 2$ even though not for Y1 or Y3.

c. Brand awareness influences the decision making process by providing the differences in source of information in the decision making process. This difference is influenced by the brand associations in the tourist's memory and directly impact on brand image of destination (Keller, 1993). The ability of tourist to remember (recall) Bali as a world tourism destination will bring about tourists to the association of cultural tourism destinations in Southeast Asia and it is enough to help building the image as a tourism destination of Asian culture and in Bali will be confirmed that the culture is more specific to the Hindu culture.

Briefly, the effect of brand destination awareness to the tourist traveling behavior vividly described by Aaker (in Ming et al., 2011) which stressed that the destination brand awareness is the beginning of the emergence of destination brand loyalty. If tourist have the awareness of a certain tourism destination because of its brand, he is likely to develop a certain image related to that destination. Consequently, the high positive images of Bali as a tourism destinations brand caused by a high awareness enlarge the chance for tourist to choose and to travel to Bali and to extend their length of stay in Bali, as shown in above analysis. All of that sequential process will eventually greatly help Bali as a tourism destination brand has strong brand equity.

\section{Effect of destination brand image on foreign tourists traveling behavior}

Based on MANOVA analysis can be obtained Multivariate Tests and Test of Between-Subjects Effects as can be seen in Table 2, Appendix 6 and Appendix 7. 
Tabel 2. Multivariate Tests and Test of Between-Subjects Effects Destination Brand Image

\begin{tabular}{|c|c|c|c|c|c|c|}
\hline \multirow[t]{3}{*}{ No } & \multirow{3}{*}{$\begin{array}{l}\text { Destination } \\
\text { Brand } \\
\text { Image } \\
\text { Parameter }\end{array}$} & Multi & \multicolumn{3}{|c|}{ Test of Between-Subjects Effects } & destination regarding beliefs, ideas, and \\
\hline & & $\begin{array}{l}\text { Sig. } \\
\text { Roy's }\end{array}$ & $\begin{array}{l}\text { Sig. Y1 } \\
\text { (Hypothesis }\end{array}$ & $\begin{array}{l}\text { Sig. Y2 } \\
\text { (Hypothesis }\end{array}$ & $\begin{array}{l}\text { Sig. Y3 } \\
\text { (Hypothes }\end{array}$ & sitourist decision-making to visit or not to visit \\
\hline & & $\begin{array}{l}\text { Largest } \\
\text { Root }\end{array}$ & & & 2c) & to certain destination. This will have an impact \\
\hline 1 & $\begin{array}{l}\text { X8 } \\
\text { Most } \\
\text { suitable } \\
\text { and } \\
\text { competitive } \\
\text { travel } \\
\text { package } \\
\text { price } \\
\end{array}$ & .361 & .726 & .667 & .648 & $\begin{array}{l}\text { future. Destination image also affects the level } \\
\text { of tourist satisfaction on his experience during } \\
\text { vacation in destinations. This will affect the } \\
\text { length of stay of tourists in Bali as well as the } \\
\text { willingness to recommend destinations Bali as }\end{array}$ \\
\hline 2 & $\begin{array}{l}\text { X14 } \\
\text { Distinctive } \\
\text { features for } \\
\text { stunning } \\
\text { natural } \\
\text { beauty }\end{array}$ & $\begin{array}{l}.000 \\
\text { (signific } \\
\text { antly } \\
\text { affects) }\end{array}$ & $\begin{array}{l}.000 \\
\text { (significantly } \\
\text { affects) }\end{array}$ & .333 & $\begin{array}{l}.000 \\
\text { (significan } \\
\text { affects) }\end{array}$ & $\begin{array}{l}\text { ationfluence on tourist traveling behavior and is } \\
\text { corfirmed in this research findings. This is also } \\
\text { supported by Hui and Wan (2003) statement } \\
\text { that the destination image affects the }\end{array}$ \\
\hline 3 & $\begin{array}{l}\text { X13 } \\
\text { Warm, } \\
\text { Politely, } \\
\text { and }\end{array}$ & $\begin{array}{l}.000 \\
\text { (signific } \\
\text { antly } \\
\text { affects) }\end{array}$ & .710 & $\begin{array}{l}.001 \\
\text { (significantly } \\
\text { affects) }\end{array}$ & $\begin{array}{l}.000 \\
\text { (significan } \\
\text { affects) }\end{array}$ & $\begin{array}{l}\text { individual's subjective perception, subsequent } \\
\text { ntly } \\
\text { behavior, and the selection of destinations. }\end{array}$ \\
\hline
\end{tabular}

friendly

local

people.

$\mathrm{Y}_{1}=$ the frequency of visiting Bali (times)

$\mathrm{Y}_{2}=$ length of stay during vacation in Bali (days)

$\mathrm{Y}_{3}=$ the frequency recommending Bali to others (times).

Source: Appendix 6 and 7

\section{a. Multivariate test}

Between group, simultaneously parameter X13 and X14 (warm, politely, and friendly local people and distinctive features for stunning natural beauty) significantly affect all together tourists traveling behavior simultaneously (Y1, Y2, Y3: the frequency of visited Bali, length of stay during in Bali length of stay during in Bali, and the frequency recommending Bali to others) (sig. Roy's Largest Root <0.05).

Based on the analysis, parameters X13 and X14 are element of Bali image as tourism destinations in the eyes of foreign tourists. Both aspects are building impression that Bali as a tourism destination is full of hospitality. Bali is also perceived as a destination that has a natural beauty that strengthening of its main tourist attraction as a cultural tourism destination. These jointly build a destination brand image of Bali as a tourism destination. Destination image itself according to
Crompton (in Jenkins, 1999) as "the sum of beliefs, ideas, and impressions that a person has of a destination" or "image of the destination regarding beliefs, ideas, and mpressions upon destination". The image of ourist decision-making to visit or not to visit to certain destination. This will have an impact on tourist decision to visit or not to Bali in the future. Destination image also affects the level of tourist satisfaction on his experience during vacation in destinations. This will affect the length of stay of tourists in Bali as well as the willingness to recommend destinations Bali as

\section{b. Test of Between-Subjects Effects}

Individually, parameter X14 significantly effect on Y1 (sig. $0.000<0.05$ ) and Y3 (sig. $0.000<0.05$ ). While, parameter X13 significantly effect on Y2 (sig. $0.001<0.05$ ) and Y3 (sig. $0.000<0.05$ ). Based on the analysis, hypotheses $2 \mathrm{a}, 2 \mathrm{~b}$, and $2 \mathrm{c}$ can be proven in this regard that destination brand image significantly affect the frequency of tourist visit to Bali, affect the length of stay during the vacation in Bali, and also affect the frequency of recommending Bali tourism destinations to others

This means that tourists Bali as a tourism destination having a high image supported by the attractiveness of natural beauty and make tourists want to visit Bali in the future and recommended Bali to others to be visited. It is quite logic considering that the hospitality of the Balinese community makes tourists comfortable so in general they can enjoy their vacation in Bali as desired.

Destination brand image is an important factor in building tourist's trust on destination. Esch et al. (in the Ming et al., 2011) states that there is a direct and indirect impact of destination brand image to tourist's trust and affecting the willingness to purchase travel package in the future. Reflecting on these results, the tourists have a good image to Bali 
as a tourism destination and have a positive influence on their trus to Bali and increase the loyalty of tourists to Bali as a tourism destinations as reflected in the increase of tourist arrivals frequency to Bali, extend their length of stay in Bali, and recommend Bali as a tourism destination to others (Ming et al., 2011). This will be very helpful for Bali to have strong brand equity.

\section{Effect of destination brand association on foreign tourists traveling behavior}

Based on MANOVA analysis can be obtained Multivariate Tests and Test of Between-Subjects Effects as can be seen in Table 3, Appendix 8 and Appendix 9.

$$
\text { Tabel } 3 .
$$

Multivariate Tests ans Test of BetweenSubjects Effects Destination Brand Association

\begin{tabular}{|c|c|c|c|c|c|}
\hline \multirow[t]{2}{*}{ No } & \multirow{2}{*}{$\begin{array}{c}\text { Desti } \\
\text { natio } \\
\mathrm{n} \\
\text { Bran } \\
\mathrm{d} \\
\text { Asso } \\
\text { ciatio } \\
\mathrm{n} \\
\text { Para } \\
\text { meter }\end{array}$} & $\begin{array}{l}\text { Multiva } \\
\text { riate }\end{array}$ & \multicolumn{3}{|c|}{$\begin{array}{c}\text { Test of Between-Subjects } \\
\text { Effects }\end{array}$} \\
\hline & & $\begin{array}{l}\text { Sig. } \\
\text { Roy's } \\
\text { Largest } \\
\text { Root }\end{array}$ & $\begin{array}{l}\text { Sig. Y1 } \\
\text { (Hypot } \\
\text { hesis } \\
\text { 3a) }\end{array}$ & $\begin{array}{l}\text { Sig. Y2 } \\
\text { (Hypot } \\
\text { hesis } \\
3 b \text { ) }\end{array}$ & $\begin{array}{l}\text { Sig. Y3 } \\
\text { (Hypot } \\
\text { hesis } \\
\text { 3c) }\end{array}$ \\
\hline 1 & $\begin{array}{l}\mathrm{X} 18 \\
\text { Bali } \\
\text { has } \\
\text { many } \\
\text { touris } \\
\mathrm{m} \\
\text { attrac } \\
\text { tions }\end{array}$ & .412 & .858 & .877 & .648 \\
\hline 2 & $\begin{array}{l}\text { X21 } \\
\text { Safe } \\
\text { and } \\
\text { peace } \\
\text { ful } \\
\text { desti } \\
\text { natio } \\
\text { n }\end{array}$ & $\begin{array}{l}.000 \\
\text { (signifi } \\
\text { cantly } \\
\text { affects) }\end{array}$ & $\begin{array}{l}.008 \\
\text { (signifi } \\
\text { cantly } \\
\text { affects) }\end{array}$ & $\begin{array}{l}.018 \\
\text { (signifi } \\
\text { cantly } \\
\text { affects) }\end{array}$ & $\begin{array}{l}.000 \\
\text { (signifi } \\
\text { cantly } \\
\text { affects) }\end{array}$ \\
\hline 3 & $\begin{array}{l}\text { X17 } \\
\text { Majo } \\
\mathrm{r} \\
\text { cultur } \\
\text { al } \\
\text { touris } \\
\mathrm{m} \\
\text { desti } \\
\text { natio } \\
\mathrm{n} \text { in } \\
\text { the } \\
\text { world }\end{array}$ & $\begin{array}{l}.024 \\
\text { (signifi } \\
\text { cantly } \\
\text { affects) }\end{array}$ & .110 & .373 & .065 \\
\hline
\end{tabular}

$Y_{1}=$ the frequency of visiting Bali (times)

$\mathrm{Y}_{2}=$ length of stay during vacation in Bali (days)

$\mathrm{Y}_{3}=$ the frequency recommending Bali to others (times).

Source: Appendix 8 and 9.

\section{a. Multivariate test}

Between group, simultaneously parameter X21 and X17 (safe and peaceful destination and major cultural tourism destination in the world) significantly affect all together tourists traveling behavior simultaneously (Y1, Y2, Y3: the frequency of visited Bali, length of stay during in Bali length of stay during in Bali, and the frequency recommending Bali to others) (sig. Roy's Largest Root <0.05).

The dominant aspects of the destination brand association Bali as a tourism destination that influence tourists traveling behavior are a sense of security and status of Bali as a major cultural tourism destination in the world. Sense of security felt by tourists during vacation in Bali is the starting point to build loyalty to the destination. This will be reinforced by many aspects of the local culture (Hindu-based culture) that different from other tourism destinations. Both of these become a starting point to build brand equity of Bali.

\section{b. Test of Between-Subjects Effects}

Individually, only parameter $\mathrm{X} 21$ significantly affects on Y1 (sig. $0.008<0.05$ ), Y2 (sig. $0.018<0.05$ ), and Y3 (sig. $0.000<$ $0.05)$. Based on the analysis, hypotheses $3 \mathrm{a}$, $3 b$, and $3 c$ can be proven in this regard that destination brand association significantly affect the frequency of tourist visit to Bali, affect the length of stay during the vacation in Bali, and also affect the frequency of recommending Bali tourism destinations to others. Interestingly, the data show that Bali is fully recovered from safety issue related to the terrorist attacks in 2002 and 2005. This means that tourists consider that those two terrorist attacks do not affect the traveling decision to Bali. A sense of security is of primary issue to traveler before traveling to any tourism destination. 
Destination brand association is any tourist mental relationships associated with a tourism destination that may involve attributes of products or services in a destination that relate either directly or indirectly with tourists (Tuominen, 1999). The destination association does not only exist but have a level of power that affects travelers in choosing Bali as a tourism destination. In this study, the most powerful association is the status of Bali as a world cultural destination and a sense of security for tourists during their vacation in Bali. Consequently, destination brand association significantly affects tourists to be repeater guests in Bali, extend the length of stay, and recommend to others.

\section{Effect of destination brand perceived quality on foreign tourists traveling behavior}

Based on MANOVA analysis can be obtained Multivariate Tests and Test of Between-Subjects Effects as can be seen in Table 4, Appendix 10 and Appendix 11.

Tabel 4. Multivariate Tests and Test of Between-Subjects Effects Destination Brand Perceived Quality

\begin{tabular}{|c|c|c|c|c|c|}
\hline \multirow[t]{2}{*}{ No } & \multirow[b]{2}{*}{$\begin{array}{c}\text { Desti } \\
\text { natio } \\
\mathrm{n} \\
\text { Bran } \\
\mathrm{d} \\
\text { Perce } \\
\text { ived } \\
\text { Quali } \\
\text { ty } \\
\text { Para } \\
\text { meter }\end{array}$} & \multirow{2}{*}{$\begin{array}{l}\begin{array}{c}\text { Multiva } \\
\text { riate } \\
\text { Tests }\end{array} \\
\text { Sig. } \\
\text { Roy's } \\
\text { Largest } \\
\text { Root }\end{array}$} & \multicolumn{3}{|c|}{$\begin{array}{c}\text { Test of Between-Subjects } \\
\text { Effects }\end{array}$} \\
\hline & & & $\begin{array}{l}\text { Sig. Y1 } \\
\text { (Hypot } \\
\text { hesis } \\
4 a \text { ) }\end{array}$ & $\begin{array}{l}\text { Sig. Y2 } \\
\text { (Hypoth } \\
\text { esis } \\
\text { 4b) }\end{array}$ & $\begin{array}{l}\text { Sig. Y3 } \\
\text { (Hypot } \\
\text { hesis } \\
4 c \text { ) }\end{array}$ \\
\hline 1 & $\begin{array}{l}\text { X32 } \\
\text { Very } \\
\text { helpf } \\
\text { ul } \\
\text { touris } \\
\text { m } \\
\text { work } \\
\text { ers }\end{array}$ & .061 & .066 & .543 & .699 \\
\hline 2 & $\begin{array}{l}\text { X27 } \\
\text { Excel } \\
\text { lent } \\
\text { touris } \\
\mathrm{m} \\
\text { physi } \\
\text { cal } \\
\text { facilit } \\
\text { ies }\end{array}$ & $\begin{array}{l}.013 \\
\text { (signific } \\
\text { antly } \\
\text { affects) }\end{array}$ & .825 & $\begin{array}{l}.042 \\
\text { (signific } \\
\text { antly } \\
\text { affects) }\end{array}$ & .910 \\
\hline 3 & $\begin{array}{l}\text { X37 } \\
\text { Provi }\end{array}$ & $\begin{array}{l}.038 \\
\text { (signific }\end{array}$ & .333 & .812 & .934 \\
\hline
\end{tabular}

http://ojs.unud.ac.id/index.php/eot

\begin{tabular}{ll}
\hline ding & antly \\
perso & affects) \\
nal & \\
care & \\
for & \\
touris & \\
ts & \\
\hline
\end{tabular}

$Y_{1}=$ the frequency of visiting Bali (times)

$\mathrm{Y}_{2}=$ length of stay during vacation in Bali (days)

$\mathrm{Y}_{3}=$ the frequency recommending Bali to others (times).

Source: Appendix 10 and 11

\section{a. Multivariate test}

Between group, simultaneously parameter X27 and X37 (very helpful tourism workers and providing personal care for tourists) significantly affect all together tourists traveling behavior simultaneously (Y1, Y2, Y3: the frequency of visited Bali, length of stay during in Bali length of stay during in Bali, and the frequency recommending Bali to others) (sig. Roy's Largest Root <0.05).

The quality of Bali as a tourism destination depends on the perception of tourists on overall superiority of Bali as a tourism destination compared to other destinations. This perception arises when foreign tourists are already consumed, experienced, and enjoyed many aspects of Bali as tourism destination. Quality in this context is the general assessment made by tourists related to the ability of Bali as a destination to meet tourist desired, to provide good facilities, to provide reliable attractions, to provide standardized services, and free from defects that cause tourists feel dissatisfied (Duffy and Ketchand, 1998; Türkyılmaz and Özkan, 2007). This is the basis for the formation of brand equity Bali as a tourism destination.

\section{b. Test of Between-Subjects Effects}

Individually, only parameter X27 (excellent tourism physical facilities) significantly effects on Y2 (sig. $0.042<0.05$ ). Based on the analysis, only hypothesis $4 \mathrm{~b}$ can be proven in this regard that destination brand perceived quality only significantly affect the length of stay during the vacation in Bali. The perception of well physical facilities quality will form the perception of overall quality on 
Bali tourism destinations and ultimately affect tourist traveling behavior in destination.

According to Ming et al. (2011) in the context of tourism, destination quality perceived by tourists generates connative response to the destinations. This determines tourists behavior. In the context of this study the behavior related to their length of stay during vacation in Bali. Studies Gil et al. (in Suh and Pedersen, 2010) showed that the higher the quality of the destination perceived by tourists the stronger possibility travelers behave positively towards that destination.

To conclude the whole picture on how brand equity of Bali as tourism destination affects tourist traveling behavior can be summarized in Table 5.

Tabel 5. The Influence of Bali Brand Equity to Tourists Traveling Behavior

\begin{tabular}{|c|c|c|c|c|c|}
\hline \multirow[t]{2}{*}{ No. } & \multirow{2}{*}{$\begin{array}{l}\text { Brand } \\
\text { equity } \\
\text { variable } \\
\text { s }\end{array}$} & \multirow[b]{2}{*}{$\begin{array}{c}\text { Affe } \\
\text { ct } \\
\text { to } \\
\text { the } \\
\text { whol } \\
\text { e } \\
\text { beha } \\
\text { vior } \\
\text { (Y1, } \\
\mathrm{Y} 2, \mathrm{Y} \\
3 \text { ) }\end{array}$} & \multicolumn{3}{|c|}{ Individual affect to behavior } \\
\hline & & & $\begin{array}{c}\text { Y1 } \\
\text { (the } \\
\text { freque } \\
\text { ncy of } \\
\text { visitin } \\
\text { g Bali) }\end{array}$ & $\begin{array}{c}\mathrm{Y} 2 \\
\text { (lengt } \\
\mathrm{h} \text { of } \\
\text { stay } \\
\text { durin } \\
\mathrm{g} \\
\text { vacati } \\
\text { on in } \\
\text { Bali) }\end{array}$ & $\begin{array}{c}\text { Y3 } \\
\text { (the } \\
\text { frequency } \\
\text { recommen } \\
\text { ding Bali } \\
\text { to others) }\end{array}$ \\
\hline 1 & $\begin{array}{l}\text { Destination } \\
\text { brand } \\
\text { awareness }\end{array}$ & $\begin{array}{l}\mathrm{X} 3 \\
\text { and } \\
\mathrm{X} 5 \\
\end{array}$ & - & $\begin{array}{l}\text { X3 } \\
\text { X5 }\end{array}$ & - \\
\hline 2 & $\begin{array}{l}\text { Destination } \\
\text { brand } \\
\text { image }\end{array}$ & $\begin{array}{l}\text { X14 } \\
\text { and } \\
\text { X13 }\end{array}$ & X14 & $\mathrm{X} 13$ & $\mathrm{X} 14, \mathrm{X} 13$ \\
\hline 3 & $\begin{array}{l}\text { Destination } \\
\text { brand } \\
\text { association }\end{array}$ & $\begin{array}{l}\text { X21 } \\
\text { and } \\
\text { X17 }\end{array}$ & $\mathrm{X} 21$ & $\mathrm{X} 21$ & $\mathrm{X} 21$ \\
\hline 4 & $\begin{array}{l}\text { Destination } \\
\text { brand } \\
\text { perceived } \\
\text { quality }\end{array}$ & $\begin{array}{l}\text { X27 } \\
\text { and } \\
\text { X37 }\end{array}$ & - & $\mathrm{X} 27$ & - \\
\hline
\end{tabular}

Tabel 5 shows that brand equity of Bali affects to whole tourism traveling behavior through destination brand awareness (X3 and X5), destination brand image (X14 and X13), destination brand association (X21 and X17), and destinastion perceived quality (X27 and X37).

Individually, the tourist traveling behavior can be seen as follow:

1. $\mathrm{Y}_{1}$ (the frequency of visiting Bali) is affected by X14 (distinctive features for stunning natural beauty) and X21 (safe and peaceful destination).

2. Y2 (length of stay during vacation in Bali) is affected by X3 (Bali as one of the world's main destination), X5 (Strong brand Bali recall), X13 (warm, politely, and friendly local people), X21(safe and peaceful destination), and X27 (excellent tourism physical facilities).

3. Y3 (the frequency recommending Bali to others) is affected by $\mathrm{X} 14$ (distinctive features for stunning natural beauty), X13 (warm, politely, and friendly local people), and X21(safe and peaceful destination).

\section{Conclusion}

The influence of Bali brand equity to tourists traveling behavior as a whole through destination brand awareness, destination brand image, destination brand association, and destinastion perceived quality. While, individually, tourists traveling behavior in Bali as a tourism destination as follow: (a) the frequency of visiting Bali is affected by distinctive features for stunning natural beauty of Bali and safe and peaceful Bali turism destination, (b) the length of stay during vacation in Bali is affected Bali as one of the world's main destination, strong brand Bali recall, warm-politely-friendly local people, safe and peaceful destination, and excellent tourism physical facilities, and (c) the frequency recommending Bali to others is affected by distinctive features for stunning natural beauty of Bali, warm-politely-friendly local people, and safe and peaceful destination.

This research shows that Bali brand equity strongly affects the behavior of foreign tourists during their vacation in Bali. Keep maintaining a high level of brand equity of Bali can be used to develop as a basis of competitive advantage compare to competitors, keep the loyalty of visitor, expand expand market segment, choose the right target market and anchoring destination position in world market competition. Give 
stressing on the attributes of destination that develop tourist's positive behavior to Bali as a tourism destination will determine the success of Bali in world tourism market competition.

\section{References}

Chang, C.-F. (2008) Effect of destination branding on tourists' attitudes toward Tamshui, Taiwan.

Chen, C.-F. and Tseng, W.-S. (2010) 'Exploring customer-based airline brand equity: Evidence from Taiwan', Transportation Journal. JSTOR, pp. 24-34.

Duffy, J. A. M. and Ketchand, A. A. (1998) 'Examining the role of service quality in overall service satisfaction', Journal of Managerial Issues. JSTOR, pp. 240-255.

Hoffman, K. D. and Bateson, J. E. G. (2010) Services marketing: concepts, strategies, \& cases. Cengage learning.

Hui, T. K. and Wan, T. W. D. (2003) 'Singapore's image as a tourist destination', International journal of tourism research. Wiley Online Library, 5(4), pp. 305-313.

Jalilvand, M. R., Esfahani, S. S. and Samiei, N. (2010) 'Destination branding and tourists' attitudes (the case of Isfahan as a tourism destination in Iran)', International Journal of Marketing Studies, 2(2), p. 235.

Jamal, A. and Naser, K. (2002) 'Customer satisfaction and retail banking: an assessment of some of the key antecedents of customer satisfaction in retail banking', international journal of bank marketing. MCB UP Ltd, 20(4), pp. 146-160.

Jenkins, O. H. (1999) 'Understanding and measuring tourist destination images', The International Journal of Tourism Research. Wiley Periodicals Inc., 1(1), p. 1.
Keller, K. L. (1993) 'Conceptualizing, measuring, and managing customerbased brand equity', the Journal of Marketing. JSTOR, pp. 1-22.

Konečnik, M. (2005) Customer-based brand equity for tourism destination: Conceptual model and its empirical verification. University of Ljubljana.

Konecnik, M. and Gartner, W. C. (2007) 'Customer-based brand equity for a destination', Annals of tourism research. Elsevier, 34(2), pp. 400421.

Konecnik Ruzzier, M. (2013) 'Clarifying the concept of customer-based brand equity for a tourism destination'.

Lee, G. C. and Leh, F. C. Y. (2011) 'Dimensions of customer-based brand equity: A study on Malaysian brands', Journal of Marketing Research and Case Studies, 2011, pp. 1-10.

Ming, T. T., Ismail, H. Bin and Rasiah, D. (2011) 'Hierarchical chain of consumer-based brand equity: Review from the fast food industry', The International Business \& Economics Research Journal. The Clute Institute, 10(9), p. 67.

Percy, L. and Rossiter, J. R. (1992) 'A model of brand awareness and brand attitude advertising strategies', Psychology \& Marketing. Wiley Online Library, 9(4), pp. 263-274.

Santoso, S. (2014) 'Statistik Multivariat Edisi Revisi Konsep dan Aplikasi dengan SPSS'. Jakarta: PT. Elex Media Komputindo.

Suh, Y. I. and Pedersen, P. M. (2010) 'Participants' service quality perceptions of fantasy sports websites: The relationship between service quality, customer satisfaction, attitude, and actual usage', Sport Marketing Quarterly. Fitness Information Technology, A Division of ICPE West Virginia University, 19(2), p. 78. 
Swarbrooke, J. and Susan, H. (2007) Consumer Behavior in Tourism (Second Edition). Oxford: Elsevier Ltd.

Türkyılmaz, A. and Özkan, C. (2007) 'Development of a customer satisfaction index model: An application to the Turkish mobile phone sector', Industrial Management \& Data Systems. Emerald Group Publishing Limited, 107(5), pp. 672687.

World Tourism Organization (2005) 'Tourism Highlight UNWTO, Tourism Barometer Volume 12'. 


\section{APPENDIXES}

Appendix 1. Sample Distribution in Each Tourism Objects

\begin{tabular}{|c|c|c|c|c|c|c|c|c|c|}
\hline \multirow[t]{15}{*}{$\begin{array}{l}\mathrm{N} \\
\mathrm{O} \\
\text {. }\end{array}$} & \multirow[t]{15}{*}{$\begin{array}{l}\text { To } \\
\text { uri } \\
\text { sm } \\
\text { obj } \\
\text { ect }\end{array}$} & \multicolumn{2}{|c|}{$\begin{array}{l}\text { Amount } \\
\text { of foreign } \\
\text { tourist } \\
\text { visi }\end{array}$} & \multirow[t]{2}{*}{$\begin{array}{l}\text { A } \\
\text { m } \\
\text { ou } \\
\text { nt } \\
\text { of }\end{array}$} & \multicolumn{5}{|c|}{$\begin{array}{l}\text { Sample proportion } \\
\text { basen on origins } \\
\text { (person) }\end{array}$} \\
\hline & & Per & Pro & & $\mathrm{E}$ & A & A & A & $\mathrm{M}$ \\
\hline & & so & por & sa & ro & si & $\mathrm{m}$ & fr & id \\
\hline & & $\mathrm{n}$ & tio & $\mathrm{m}$ & $\mathrm{p}$ & $\mathrm{a}$ & eri & ic & le \\
\hline & & & $\mathrm{n}$ & $\mathrm{pl}$ & $\mathrm{a}$ & $\mathrm{Pa}$ & ca & $\mathrm{a}$ & $\mathrm{E}$ \\
\hline & & & & e & & sif & & & $\mathrm{a}$ \\
\hline & & & & $(\mathrm{p}$ & (5 & ic- & (1 & (5 & st \\
\hline & & & & er & 2 & $\mathrm{O}$ & 5 & $\%$ & ( \\
\hline & & & & so & $\%$ & se & $\%)$ & ) & 5 \\
\hline & & & & n) & ) & an & & & $\%$ \\
\hline & & & & & & ia & & & ) \\
\hline & & & & & & (2 & & & \\
\hline & & & & & & 3 & & & \\
\hline & & & & & & $\%$ & & & \\
\hline & & & & & & ) & & & \\
\hline 1 & $\mathrm{Ta}$ & 1.2 & 0 & 1 & 5 & 2 & 1 & 5 & 5 \\
\hline & na & 40. & 45 & 0 & 6 & 5 & 6 & & \\
\hline & $\mathrm{h}$ & 94 & & 7 & & & & & \\
\hline & Lot & 5 & & & & & & & \\
\hline 2 & Ul & 50 & 0 & 4 & 2 & 1 & 7 & 2 & 2 \\
\hline & un & 7.6 & 18 & 4 & 3 & 0 & & & \\
\hline & $\mathrm{Da}$ & 22 & & & & & & & \\
\hline & nu & & & & & & & & \\
\hline & $\mathrm{Be}$ & & & & & & & & \\
\hline & rat & & & & & & & & \\
\hline & an & & & & & & & & \\
\hline 3 & Ul & 49 & 0 , & 4 & 2 & 1 & 6 & 2 & 2 \\
\hline & uw & 8.0 & 18 & 3 & 2 & 0 & & & \\
\hline & atu & 70 & & & & & & & \\
\hline 4 & $\mathrm{Pe}$ & 31 & 0 , & 2 & 1 & 6 & 4 & 2 & 2 \\
\hline & nel & 8.5 & 11 & 8 & 4 & & & & \\
\hline & ok & 64 & & & & & & & \\
\hline & an & & & & & & & & \\
\hline & Bat & & & & & & & & \\
\hline & ur & & & & & & & & \\
\hline 5 & $\mathrm{Ta}$ & 20 & 0 , & 1 & 9 & 4 & 3 & 1 & 1 \\
\hline & $\mathrm{ma}$ & 5.5 & 07 & 8 & & & & & \\
\hline & $\mathrm{n}$ & 25 & & & & & & & \\
\hline & Ay & & & & & & & & \\
\hline & un & & & & & & & & \\
\hline & Tot & 2.7 & 1,0 & 2 & 1 & 5 & 3 & 1 & 1 \\
\hline & al & 70 . & 0 & 4 & 2 & 5 & 6 & 2 & 2 \\
\hline & & 72 & & 0 & 5 & & & & \\
\hline & & 6 & & & & & & & \\
\hline
\end{tabular}

Appendix 2. Reliabilitity test of questioner

Case Processing Summary
\begin{tabular}{|ll|r|r|}
\hline & \multicolumn{1}{|c|}{$\mathrm{N}$} & \multicolumn{1}{|c|}{$\%$} \\
\hline Cases & Valid & 240 & 100.0 \\
& Excluded $^{\mathrm{a}}$ & 0 & .0 \\
& Total & 240 & 100.0 \\
\hline
\end{tabular}

a. Listwise deletion based on all variables in the procedure.

\section{Reliability Statistics}

\begin{tabular}{|r|r|}
\hline Cronbach's Alpha & N of Items \\
\hline .917 & 41 \\
\hline
\end{tabular}


Appendix 3. Validity test of questioner

Item-Total Statistics

\begin{tabular}{|c|c|c|c|c|}
\hline & $\begin{array}{l}\text { Scale } \\
\text { Mean if } \\
\text { Item } \\
\text { Deleted }\end{array}$ & $\begin{array}{c}\text { Scale } \\
\text { Variance } \\
\text { if Item } \\
\text { Deleted }\end{array}$ & $\begin{array}{c}\text { Correcte } \\
\text { d Item- } \\
\text { Total } \\
\text { Correlati } \\
\text { on }\end{array}$ & $\begin{array}{l}\text { Cronbach's Alpha } \\
\text { if Item Deleted }\end{array}$ \\
\hline X1 & 171.40 & 170.333 & .369 & .916 \\
\hline X2 & 171.40 & 170.767 & .323 & .917 \\
\hline X3 & 171.32 & 170.170 & .367 & .916 \\
\hline X4 & 171.44 & 168.264 & .412 & .916 \\
\hline X5 & 171.33 & 169.119 & .453 & .915 \\
\hline X6 & 171.43 & 168.949 & .432 & .916 \\
\hline X7 & 171.56 & 164.942 & .450 & .916 \\
\hline X8 & 171.40 & 167.438 & .517 & .915 \\
\hline X9 & 171.67 & 165.001 & .477 & .915 \\
\hline$X 10$ & 171.58 & 167.701 & .466 & .915 \\
\hline$X 11$ & 171.69 & 166.909 & .397 & .916 \\
\hline $\mathrm{X} 12$ & 171.55 & 169.973 & .308 & .917 \\
\hline$X 13$ & 171.50 & 168.686 & .416 & .916 \\
\hline X14 & 171.40 & 169.044 & .388 & .916 \\
\hline X15 & 171.54 & 165.120 & .589 & .914 \\
\hline$X 16$ & 171.60 & 165.035 & .602 & .914 \\
\hline X17 & 171.57 & 166.019 & .510 & .915 \\
\hline X18 & 171.50 & 168.033 & .470 & .915 \\
\hline X19 & 171.69 & 164.115 & .522 & .914 \\
\hline X20 & 171.57 & 165.141 & .564 & .914 \\
\hline X21 & 171.55 & 167.638 & .448 & .915 \\
\hline X22 & 171.58 & 166.328 & .519 & .914 \\
\hline X23 & 171.72 & 165.785 & .524 & .914 \\
\hline X24 & 171.75 & 164.542 & .572 & .914 \\
\hline X25 & 171.65 & 165.652 & .570 & .914 \\
\hline X26 & 171.67 & 165.971 & .581 & .914 \\
\hline X27 & 171.46 & 167.890 & .445 & .915 \\
\hline X28 & 171.62 & 169.384 & .414 & .916 \\
\hline X29 & 171.71 & 168.348 & .416 & .916 \\
\hline X30 & 171.54 & 169.898 & .344 & .916 \\
\hline X31 & 171.60 & 171.236 & .260 & .917 \\
\hline X32 & 171.40 & 168.602 & .436 & .915 \\
\hline X33 & 171.46 & 168.258 & .448 & .915 \\
\hline X34 & 171.72 & 168.629 & .370 & .916 \\
\hline X35 & 171.58 & 170.069 & .347 & .916 \\
\hline X36 & 171.67 & 168.909 & .337 & .917 \\
\hline X37 & 171.52 & 168.393 & .430 & .916 \\
\hline X38 & 171.69 & 168.492 & .337 & .917 \\
\hline X39 & 171.53 & 168.769 & .434 & .915 \\
\hline$X 40$ & 171.58 & 168.336 & .429 & .916 \\
\hline X41 & 171.69 & 166.241 & .467 & .915 \\
\hline
\end{tabular}

Appendix 4. Multivariate Test of Destination Brand Awareness

Multivariate Tests $^{\mathrm{c}}$

\begin{tabular}{|c|c|c|c|c|c|c|}
\hline \multicolumn{2}{|c|}{ Effect } & Value & $\mathrm{F}$ & $\begin{array}{c}\text { Hypot } \\
\text { hesis } \\
\text { df }\end{array}$ & Error df & Sig. \\
\hline \multirow{4}{*}{$\begin{array}{l}\text { Inter } \\
\text { cept }\end{array}$} & Pillai's Trace & .136 & $11.657^{\mathrm{a}}$ & 3.000 & 222.000 & .000 \\
\hline & Wilks' Lambda & .864 & $11.657^{\mathrm{a}}$ & 3.000 & 222.000 & .000 \\
\hline & Hotelling's Trace & .158 & $11.657^{\mathrm{a}}$ & 3.000 & 222.000 & .000 \\
\hline & $\begin{array}{l}\text { Roy's Largest } \\
\text { Root }\end{array}$ & .158 & $11.657^{\mathrm{a}}$ & 3.000 & 222.000 & .000 \\
\hline \multirow[t]{4}{*}{ X3 } & Pillai's Trace & .062 & 2.375 & 6.000 & 446.000 & .029 \\
\hline & Wilks' Lambda & .939 & $2.378^{a}$ & 6.000 & 444.000 & .028 \\
\hline & Hotelling's Trace & .065 & 2.382 & 6.000 & 442.000 & .028 \\
\hline & $\begin{array}{l}\text { Roy's Largest } \\
\text { Root }\end{array}$ & .052 & $3.875^{b}$ & 3.000 & 223.000 & .010 \\
\hline \multirow[t]{4}{*}{ X5 } & Pillai's Trace & .052 & 1.323 & 9.000 & 672.000 & .221 \\
\hline & Wilks' Lambda & .948 & 1.328 & 9.000 & 540.440 & .219 \\
\hline & Hotelling's Trace & .054 & 1.330 & 9.000 & 662.000 & .218 \\
\hline & $\begin{array}{l}\text { Roy's Largest } \\
\text { Root }\end{array}$ & .045 & $3.351^{b}$ & 3.000 & 224.000 & .020 \\
\hline \multirow[t]{4}{*}{ X2 } & Pillai's Trace & .011 & .413 & 6.000 & 446.000 & .871 \\
\hline & Wilks' Lambda & .989 & $.411^{\mathrm{a}}$ & 6.000 & 444.000 & .872 \\
\hline & Hotelling's Trace & .011 & .409 & 6.000 & 442.000 & .873 \\
\hline & $\begin{array}{l}\text { Roy's Largest } \\
\text { Root }\end{array}$ & .007 & $.492^{b}$ & 3.000 & 223.000 & .688 \\
\hline \multirow{4}{*}{$\begin{array}{l}X 3 \\
x 5\end{array}$} & Pillai's Trace & .071 & 1.819 & 9.000 & 672.000 & .062 \\
\hline & Wilks' Lambda & .929 & 1.834 & 9.000 & 540.440 & .060 \\
\hline & Hotelling's Trace & .075 & 1.843 & 9.000 & 662.000 & .058 \\
\hline & $\begin{array}{l}\text { Roy's Largest } \\
\text { Root }\end{array}$ & .063 & $4.712^{b}$ & 3.000 & 224.000 & .003 \\
\hline \multirow{4}{*}{$\begin{array}{l}X 3 * \\
X 2\end{array}$} & Pillai's Trace & .024 & .914 & 6.000 & 446.000 & .485 \\
\hline & Wilks' Lambda & .976 & $.912^{\mathrm{a}}$ & 6.000 & 444.000 & .486 \\
\hline & Hotelling's Trace & .025 & .911 & 6.000 & 442.000 & .487 \\
\hline & $\begin{array}{l}\text { Roy's Largest } \\
\text { Root }\end{array}$ & .021 & $1.570^{b}$ & 3.000 & 223.000 & .197 \\
\hline \multirow{4}{*}{$\begin{array}{l}X 5^{*} \\
X 2\end{array}$} & Pillai's Trace & .006 & .238 & 6.000 & 446.000 & .964 \\
\hline & Wilks' Lambda & .994 & $.237^{\mathrm{a}}$ & 6.000 & 444.000 & .964 \\
\hline & Hotelling's Trace & .006 & .236 & 6.000 & 442.000 & .964 \\
\hline & $\begin{array}{l}\text { Roy's Largest } \\
\text { Root }\end{array}$ & .005 & $.395^{b}$ & 3.000 & 223.000 & .757 \\
\hline \multirow{4}{*}{$\begin{array}{l}X 3{ }^{*} \\
X 5{ }^{*} \\
X 2\end{array}$} & Pillai's Trace & .005 & $.352^{\mathrm{a}}$ & 3.000 & 222.000 & .788 \\
\hline & Wilks' Lambda & .995 & $.352^{\mathrm{a}}$ & 3.000 & 222.000 & .788 \\
\hline & Hotelling's Trace & .005 & $.352^{\mathrm{a}}$ & 3.000 & 222.000 & .788 \\
\hline & $\begin{array}{l}\text { Roy's Largest } \\
\text { Root }\end{array}$ & .005 & $.352^{\mathrm{a}}$ & 3.000 & 222.000 & .788 \\
\hline
\end{tabular}

a. Exact statistic

b. The statistic is an upper bound on $F$ that yields a lower bound on the significance level.

c. Design: Intercept $+\mathrm{X} 3+\mathrm{X} 5+\mathrm{X} 2+\mathrm{X} 3{ }^{*} \mathrm{X} 5+\mathrm{X} 3{ }^{*} \mathrm{X} 2+$ $\mathrm{X} 5{ }^{*} \mathrm{X} 2+\mathrm{X} 3{ }^{*} \mathrm{X} 5{ }^{*} \mathrm{X} 2$ 
Appendix 5. Test of Between-Subjects Effects Destination Brand Awareness

\begin{tabular}{|c|c|c|c|c|c|c|}
\hline $\begin{array}{l}\text { Sourc } \\
\text { e }\end{array}$ & $\begin{array}{l}\text { Dependent } \\
\text { Variable }\end{array}$ & $\begin{array}{l}\text { Type III Sum } \\
\text { of Squares }\end{array}$ & $\mathrm{df}$ & $\begin{array}{l}\text { Mean } \\
\text { Square }\end{array}$ & $\mathrm{F}$ & Sig. \\
\hline \multirow{3}{*}{$\begin{array}{l}\text { Corre } \\
\text { cted } \\
\text { Model }\end{array}$} & Y1_FR_KUNJ & $754.081^{\mathrm{a}}$ & 15 & 50.272 & .584 & .885 \\
\hline & Y2_TINGGAL & $9041.080^{\mathrm{b}}$ & 15 & 602.739 & 1.906 & .024 \\
\hline & Y3_REKOMEND & $1174.858^{c}$ & 15 & 78.324 & 1.070 & .386 \\
\hline \multirow{3}{*}{$\begin{array}{l}\text { Interc } \\
\text { ept }\end{array}$} & Y1_FR_KUNJ & 896.648 & 1 & 896.648 & 10.423 & .001 \\
\hline & Y2_TINGGAL & 8069.821 & 1 & 8069.821 & 25.513 & .000 \\
\hline & Y3_REKOMEND & 1511.340 & 1 & 1511.340 & 20.647 & .000 \\
\hline \multirow[t]{3}{*}{ X3 } & Y1_FR_KUNJ & 140.024 & 2 & 70.012 & .814 & .444 \\
\hline & Y2_TINGGAL & 2174.808 & 2 & 1087.404 & 3.438 & .034 \\
\hline & Y3_REKOMEND & 326.415 & 2 & 163.207 & 2.230 & .110 \\
\hline \multirow[t]{3}{*}{ x5 } & Y1_FR_KUNJ & 47.171 & 3 & 15.724 & .183 & .908 \\
\hline & Y2_TINGGAL & 2646.721 & 3 & 882.240 & 2.789 & .041 \\
\hline & Y3_REKOMEND & 85.956 & 3 & 28.652 & .391 & .759 \\
\hline \multirow[t]{3}{*}{$\mathrm{X} 2$} & Y1_FR_KUNJ & 95.951 & 2 & 47.975 & .558 & .573 \\
\hline & Y2_TINGGAL & 225.656 & 2 & 112.828 & .357 & .700 \\
\hline & Y3_REKOMEND & 22.166 & 2 & 11.083 & .151 & .860 \\
\hline \multirow{3}{*}{$\begin{array}{l}X 3{ }^{*} \\
X 5\end{array}$} & Y1_FR_KUNJ & 116.983 & 3 & 38.994 & .453 & .715 \\
\hline & Y2_TINGGAL & 4363.559 & 3 & 1454.520 & 4.599 & .004 \\
\hline & Y3_REKOMEND & 83.154 & 3 & 27.718 & .379 & .768 \\
\hline \multirow{3}{*}{$\begin{array}{l}X 3 * \\
X 2\end{array}$} & Y1_FR_KUNJ & 119.265 & 2 & 59.633 & .693 & .501 \\
\hline & Y2_TINGGAL & 448.505 & 2 & 224.253 & .709 & .493 \\
\hline & Y3_REKOMEND & 215.386 & 2 & 107.693 & 1.471 & .232 \\
\hline \multirow{3}{*}{$\begin{array}{l}X 5 \text { * } \\
X 2\end{array}$} & Y1_FR_KUNJ & 42.628 & 2 & 21.314 & .248 & .781 \\
\hline & Y2_TINGGAL & 111.004 & 2 & 55.502 & .175 & .839 \\
\hline & Y3_REKOMEND & 6.116 & 2 & 3.058 & .042 & .959 \\
\hline \multirow{3}{*}{$\begin{array}{l}X 3 \text { * } \\
X 5 \text { * } \\
X 2\end{array}$} & Y1_FR_KUNJ & 39.431 & 1 & 39.431 & .458 & .499 \\
\hline & Y2_TINGGAL & 56.025 & 1 & 56.025 & .177 & .674 \\
\hline & Y3_REKOMEND & 77.158 & 1 & 77.158 & 1.054 & .306 \\
\hline \multirow[t]{3}{*}{ Error } & Y1_FR_KUNJ & 19269.852 & 224 & 86.026 & & \\
\hline & Y2_TINGGAL & 70851.253 & 224 & 316.300 & & \\
\hline & Y3_REKOMEND & 16396.475 & 224 & 73.199 & & \\
\hline \multirow[t]{3}{*}{ Total } & Y1_FR_KUNJ & 27240.000 & 240 & & & \\
\hline & Y2_TINGGAL & 158374.000 & 240 & & & \\
\hline & Y3_REKOMEND & 30478.000 & 240 & & & \\
\hline \multirow{3}{*}{$\begin{array}{l}\text { Corre } \\
\text { cted } \\
\text { Total }\end{array}$} & Y1_FR_KUNJ & 20023.933 & 239 & & & \\
\hline & Y2_TINGGAL & 79892.333 & 239 & & & \\
\hline & Y3_REKOMEND & 17571.333 & 239 & & & \\
\hline \multicolumn{7}{|c|}{$\begin{array}{l}\text { a. R Squared }=.038 \text { (Adjusted R Squared }=- \\
.027 \text { ) }\end{array}$} \\
\hline \multicolumn{7}{|c|}{$\begin{array}{l}\text { b. R Squared }=.113 \text { (Adjusted R Squared }= \\
.054)\end{array}$} \\
\hline \multicolumn{7}{|c|}{$\begin{array}{l}\text { c. R Squared }=.067 \text { (Adjusted R Squared }= \\
.004)\end{array}$} \\
\hline
\end{tabular}

Appendix 6. Multivariate Test of Destination Brand Image

\begin{tabular}{|c|c|c|c|c|c|c|}
\hline \multicolumn{7}{|c|}{ Multivariate Tests $^{c}$} \\
\hline \multicolumn{2}{|l|}{ Effect } & Value & $\mathrm{F}$ & Hypothesis df & Error df & Sig. \\
\hline \multirow[t]{4}{*}{ Intercept } & Pillai's Trace & .255 & $24.679^{\mathrm{a}}$ & 3.000 & 216.000 & .000 \\
\hline & $\begin{array}{l}\text { Wilks' } \\
\text { Lambda }\end{array}$ & .745 & $24.679^{\mathrm{a}}$ & 3.000 & 216.000 & .000 \\
\hline & $\begin{array}{l}\text { Hotelling's } \\
\text { Trace }\end{array}$ & .343 & $24.679^{\mathrm{a}}$ & 3.000 & 216.000 & .000 \\
\hline & $\begin{array}{l}\text { Roy's } \\
\text { Largest Root }\end{array}$ & .343 & $24.679^{\mathrm{a}}$ & 3.000 & 216.000 & .000 \\
\hline \multirow[t]{4}{*}{ X8 } & Pillai's Trace & .019 & .470 & 9.000 & 654.000 & .895 \\
\hline & $\begin{array}{l}\text { Wilks' } \\
\text { Lambda }\end{array}$ & .981 & .467 & 9.000 & 525.838 & .897 \\
\hline & $\begin{array}{l}\text { Hotelling's } \\
\text { Trace }\end{array}$ & .019 & .465 & 9.000 & 644.000 & .898 \\
\hline & $\begin{array}{l}\text { Roy's } \\
\text { Largest Root }\end{array}$ & .015 & $1.073^{\mathrm{b}}$ & 3.000 & 218.000 & .361 \\
\hline \multirow[t]{4}{*}{$\mathrm{X} 14$} & Pillai's Trace & .136 & 3.439 & 9.000 & 654.000 & .000 \\
\hline & $\begin{array}{l}\text { Wilks' } \\
\text { Lambda }\end{array}$ & .866 & 3.549 & 9.000 & 525.838 & .000 \\
\hline & $\begin{array}{l}\text { Hotelling's } \\
\text { Trace }\end{array}$ & .152 & 3.629 & 9.000 & 644.000 & .000 \\
\hline & $\begin{array}{l}\text { Roy's } \\
\text { Largest Root }\end{array}$ & .136 & $9.897^{b}$ & 3.000 & 218.000 & .000 \\
\hline \multirow[t]{4}{*}{$\mathrm{X} 13$} & Pillai's Trace & .208 & 5.427 & 9.000 & 654.000 & .000 \\
\hline & $\begin{array}{l}\text { Wilks' } \\
\text { Lambda }\end{array}$ & .794 & 5.814 & 9.000 & 525.838 & .000 \\
\hline & $\begin{array}{l}\text { Hotelling's } \\
\text { Trace }\end{array}$ & .257 & 6.124 & 9.000 & 644.000 & .000 \\
\hline & $\begin{array}{l}\text { Roy's } \\
\text { Largest Root }\end{array}$ & .245 & $17.796^{\mathrm{b}}$ & 3.000 & 218.000 & .000 \\
\hline \multirow[t]{4}{*}{$x 8$ * X14 } & Pillai's Trace & .018 & .438 & 9.000 & 654.000 & .914 \\
\hline & $\begin{array}{l}\text { Wilks' } \\
\text { Lambda }\end{array}$ & .982 & .436 & 9.000 & 525.838 & .916 \\
\hline & $\begin{array}{l}\text { Hotelling's } \\
\text { Trace }\end{array}$ & .018 & .435 & 9.000 & 644.000 & .917 \\
\hline & $\begin{array}{l}\text { Roy's } \\
\text { Largest Root }\end{array}$ & .015 & $1.114^{b}$ & 3.000 & 218.000 & .344 \\
\hline \multirow[t]{4}{*}{$x 8$ * X13 } & Pillai's Trace & .006 & .146 & 9.000 & 654.000 & .998 \\
\hline & $\begin{array}{l}\text { Wilks' } \\
\text { Lambda }\end{array}$ & .994 & .145 & 9.000 & 525.838 & .998 \\
\hline & $\begin{array}{l}\text { Hotelling's } \\
\text { Trace }\end{array}$ & .006 & .144 & 9.000 & 644.000 & .998 \\
\hline & $\begin{array}{l}\text { Roy's } \\
\text { Largest Root }\end{array}$ & .005 & $.390^{\mathrm{b}}$ & 3.000 & 218.000 & .760 \\
\hline \multirow[t]{4}{*}{$\mathrm{X} 14{ }^{*} \mathrm{X} 13$} & Pillai's Trace & .025 & .926 & 6.000 & 434.000 & .476 \\
\hline & $\begin{array}{l}\text { Wilks' } \\
\text { Lambda }\end{array}$ & .975 & $.927^{\mathrm{a}}$ & 6.000 & 432.000 & .475 \\
\hline & $\begin{array}{l}\text { Hotelling's } \\
\text { Trace }\end{array}$ & .026 & .928 & 6.000 & 430.000 & .475 \\
\hline & $\begin{array}{l}\text { Roy's } \\
\text { Largest Root }\end{array}$ & .025 & $1.791^{\mathrm{b}}$ & 3.000 & 217.000 & .150 \\
\hline \multirow[t]{4}{*}{$X 8{ }^{*} \mathrm{X} 14{ }^{*} \mathrm{X} 13$} & Pillai's Trace & .012 & $.850^{\mathrm{a}}$ & 3.000 & 216.000 & .468 \\
\hline & $\begin{array}{l}\text { Wilks' } \\
\text { Lambda }\end{array}$ & .988 & $.850^{\mathrm{a}}$ & 3.000 & 216.000 & .468 \\
\hline & $\begin{array}{l}\text { Hotelling's } \\
\text { Trace }\end{array}$ & .012 & $.850^{\mathrm{a}}$ & 3.000 & 216.000 & .468 \\
\hline & $\begin{array}{l}\text { Roy's } \\
\text { Largest Root }\end{array}$ & .012 & $.850^{\mathrm{a}}$ & 3.000 & 216.000 & .468 \\
\hline
\end{tabular}

b. The statistic is an upper bound on $\mathrm{F}$ that yields a lower bound on the significance level. c. Design: Intercept $+\mathrm{X} 8+\mathrm{X} 14+\mathrm{X} 13+\mathrm{X} 8{ }^{*} \mathrm{X} 14+\mathrm{X} 8{ }^{*} \mathrm{X} 13+\mathrm{X} 14{ }^{*} \mathrm{X} 13+\mathrm{X} 8{ }^{*} \mathrm{X} 14$ * $\mathrm{X} 13$ 
Appendix 7. Test of Between-Subjects Effects Destination Brand Image

Tests of Between-Subjects Effects

\begin{tabular}{|c|c|c|c|c|c|c|}
\hline Source & $\begin{array}{l}\text { Dependent } \\
\text { Variable }\end{array}$ & $\begin{array}{l}\text { Type III } \\
\text { Sum of } \\
\text { Squares }\end{array}$ & df & $\begin{array}{l}\text { Mean } \\
\text { Square }\end{array}$ & $\mathrm{F}$ & Sig. \\
\hline \multirow{3}{*}{$\begin{array}{l}\text { Corrected } \\
\text { Model }\end{array}$} & Y1_FR_KUNJ & $2633.292^{\mathrm{a}}$ & 21 & 125.395 & 1.572 & .058 \\
\hline & Y2_TINGGAL & $9506.476^{\mathrm{b}}$ & 21 & 452.689 & 1.402 & .119 \\
\hline & Y3_REKOMEND & $4361.673^{c}$ & 21 & 207.699 & 3.428 & .000 \\
\hline \multirow[t]{3}{*}{ Intercept } & Y1_FR_KUNJ & 1566.853 & 1 & 1566.853 & 19.641 & .000 \\
\hline & Y2_TINGGAL & 12287.334 & 1 & 12287.334 & 38.056 & .000 \\
\hline & Y3_REKOMEND & 3460.674 & 1 & 3460.674 & 57.112 & .000 \\
\hline \multirow[t]{3}{*}{ X8 } & Y1_FR_KUNJ & 104.798 & 3 & 34.933 & .438 & .726 \\
\hline & Y2_TINGGAL & 477.895 & 3 & 159.298 & .493 & .687 \\
\hline & Y3_REKOMEND & 100.033 & 3 & 33.344 & .550 & .648 \\
\hline \multirow[t]{3}{*}{$\mathrm{X} 14$} & Y1_FR_KUNJ & 1752.711 & 3 & 584.237 & 7.324 & .000 \\
\hline & Y2_TINGGAL & 1106.090 & 3 & 368.697 & 1.142 & .333 \\
\hline & Y3_REKOMEND & 1506.116 & 3 & 502.039 & 8.285 & .000 \\
\hline \multirow[t]{3}{*}{$\mathrm{X} 13$} & Y1_FR_KUNJ & 110.420 & 3 & 36.807 & .461 & .710 \\
\hline & Y2_TINGGAL & 5610.256 & 3 & 1870.085 & 5.792 & .001 \\
\hline & Y3_REKOMEND & 1753.694 & 3 & 584.565 & 9.647 & .000 \\
\hline \multirow[t]{3}{*}{$X 8{ }^{*} X 14$} & Y1_FR_KUNJ & 47.105 & 3 & 15.702 & .197 & .898 \\
\hline & Y2_TINGGAL & 656.759 & 3 & 218.920 & .678 & .566 \\
\hline & Y3_REKOMEND & 44.347 & 3 & 14.782 & .244 & .866 \\
\hline \multirow[t]{3}{*}{$x 8 * x 13$} & Y1_FR_KUNJ & 56.062 & 3 & 18.687 & .234 & .872 \\
\hline & Y2_TINGGAL & 174.431 & 3 & 58.144 & .180 & .910 \\
\hline & Y3_REKOMEND & 53.154 & 3 & 17.718 & .292 & .831 \\
\hline \multirow{3}{*}{$\begin{array}{l}\mathrm{X} 14^{*} \\
\mathrm{X} 13\end{array}$} & Y1_FR_KUNJ & 24.486 & 2 & 12.243 & .153 & .858 \\
\hline & Y2_TINGGAL & 20.341 & 2 & 10.170 & .032 & .969 \\
\hline & Y3_REKOMEND & 250.056 & 2 & 125.028 & 2.063 & .130 \\
\hline \multirow{3}{*}{$\begin{array}{l}X 8{ }^{*} \mathrm{X} 14 \\
{ }^{*} \mathrm{X} 13\end{array}$} & Y1_FR_KUNJ & .146 & 1 & .146 & .002 & .966 \\
\hline & Y2_TINGGAL & 47.824 & 1 & 47.824 & .148 & .701 \\
\hline & Y3_REKOMEND & 76.345 & 1 & 76.345 & 1.260 & .263 \\
\hline \multirow[t]{3}{*}{ Error } & Y1_FR_KUNJ & 17390.642 & 218 & 79.774 & & \\
\hline & Y2_TINGGAL & 70385.858 & 218 & 322.871 & & \\
\hline & Y3_REKOMEND & 13209.661 & 218 & 60.595 & & \\
\hline \multirow[t]{3}{*}{ Total } & Y1_FR_KUNJ & 27240.000 & 240 & & & \\
\hline & Y2_TINGGAL & 158374.000 & 240 & & & \\
\hline & Y3_REKOMEND & 30478.000 & 240 & & & \\
\hline \multirow{3}{*}{$\begin{array}{l}\text { Corrected } \\
\text { Total }\end{array}$} & Y1_FR_KUNJ & 20023.933 & 239 & & & \\
\hline & Y2_TINGGAL & 79892.333 & 239 & & & \\
\hline & Y3_REKOMEND & 17571.333 & 239 & & & \\
\hline \multicolumn{7}{|c|}{$\begin{array}{l}\text { a. R Squared }=.132 \text { (Adjusted R Squared }= \\
.048)\end{array}$} \\
\hline \multicolumn{7}{|c|}{$\begin{array}{l}\text { b. } R \text { Squared }=.119 \text { (Adjusted R Squared }= \\
.034)\end{array}$} \\
\hline \multicolumn{7}{|c|}{$\begin{array}{l}\text { c. R Squared }=.248 \text { (Adjusted R Squared }= \\
.176)\end{array}$} \\
\hline
\end{tabular}

c. R Squared $=.248$ (Adjusted R Squared $=$ $.176)$

\section{Appendix 8. Multivariate Test ofDestination Brand Association}

\begin{tabular}{|c|c|c|c|c|c|c|}
\hline \multicolumn{7}{|c|}{ Multivariate Tests $^{c}$} \\
\hline \multicolumn{2}{|l|}{ Effect } & Value & $\mathrm{F}$ & Hypothesis df & Error df & Sig. \\
\hline \multirow[t]{4}{*}{ Intercept } & Pillai's Trace & .279 & $27.237^{\mathrm{a}}$ & 3.000 & 211.000 & .000 \\
\hline & $\begin{array}{l}\text { Wilks' } \\
\text { Lambda }\end{array}$ & .721 & $27.237^{\mathrm{a}}$ & 3.000 & 211.000 & .000 \\
\hline & $\begin{array}{l}\text { Hotelling's } \\
\text { Trace }\end{array}$ & .387 & $27.237^{\mathrm{a}}$ & 3.000 & 211.000 & .000 \\
\hline & $\begin{array}{l}\text { Roy's } \\
\text { Largest Root }\end{array}$ & .387 & $27.237^{\mathrm{a}}$ & 3.000 & 211.000 & .000 \\
\hline \multirow[t]{4}{*}{ X18 } & Pillai's Trace & .018 & .425 & 9.000 & 639.000 & .922 \\
\hline & $\begin{array}{l}\text { Wilks' } \\
\text { Lambda }\end{array}$ & .982 & .422 & 9.000 & 513.669 & .923 \\
\hline & $\begin{array}{l}\text { Hotelling's } \\
\text { Trace }\end{array}$ & .018 & .420 & 9.000 & 629.000 & .925 \\
\hline & $\begin{array}{l}\text { Roy's } \\
\text { Largest Root }\end{array}$ & .014 & $.962^{\mathrm{b}}$ & 3.000 & 213.000 & .412 \\
\hline \multirow[t]{4}{*}{$\mathrm{X} 21$} & Pillai's Trace & .189 & 3.581 & 12.000 & 639.000 & .000 \\
\hline & $\begin{array}{l}\text { Wilks' } \\
\text { Lambda }\end{array}$ & .819 & 3.656 & 12.000 & 558.545 & .000 \\
\hline & $\begin{array}{l}\text { Hotelling's } \\
\text { Trace }\end{array}$ & .212 & 3.705 & 12.000 & 629.000 & .000 \\
\hline & $\begin{array}{l}\text { Roy's } \\
\text { Largest Root }\end{array}$ & .149 & $7.921^{b}$ & 4.000 & 213.000 & .000 \\
\hline \multirow[t]{4}{*}{ X17 } & Pillai's Trace & .069 & 1.250 & 12.000 & 639.000 & .245 \\
\hline & $\begin{array}{l}\text { Wilks' } \\
\text { Lambda }\end{array}$ & .932 & 1.253 & 12.000 & 558.545 & .243 \\
\hline & $\begin{array}{l}\text { Hotelling's } \\
\text { Trace }\end{array}$ & .072 & 1.254 & 12.000 & 629.000 & .242 \\
\hline & $\begin{array}{l}\text { Roy's } \\
\text { Largest Root }\end{array}$ & .054 & $2.865^{\mathrm{b}}$ & 4.000 & 213.000 & .024 \\
\hline \multirow[t]{4}{*}{$X 18$ * X21 } & Pillai's Trace & .016 & .377 & 9.000 & 639.000 & .946 \\
\hline & $\begin{array}{l}\text { Wilks' } \\
\text { Lambda }\end{array}$ & .984 & .374 & 9.000 & 513.669 & .947 \\
\hline & $\begin{array}{l}\text { Hotelling's } \\
\text { Trace }\end{array}$ & .016 & .372 & 9.000 & 629.000 & .949 \\
\hline & $\begin{array}{l}\text { Roy's } \\
\text { Largest Root }\end{array}$ & .009 & $.656^{\mathrm{b}}$ & 3.000 & 213.000 & .580 \\
\hline \multirow[t]{4}{*}{$\mathrm{X} 18^{*} \mathrm{X} 17$} & Pillai's Trace & .032 & .466 & 15.000 & 639.000 & .957 \\
\hline & $\begin{array}{l}\text { Wilks' } \\
\text { Lambda }\end{array}$ & .968 & .462 & 15.000 & 582.879 & .958 \\
\hline & $\begin{array}{l}\text { Hotelling's } \\
\text { Trace }\end{array}$ & .033 & .459 & 15.000 & 629.000 & .960 \\
\hline & $\begin{array}{l}\text { Roy's } \\
\text { Largest Root }\end{array}$ & .015 & $.643^{\mathrm{b}}$ & 5.000 & 213.000 & .667 \\
\hline \multirow[t]{4}{*}{$\mathrm{X} 21{ }^{*} \mathrm{X} 17$} & Pillai's Trace & .179 & 3.388 & 12.000 & 639.000 & .000 \\
\hline & $\begin{array}{l}\text { Wilks' } \\
\text { Lambda }\end{array}$ & .825 & 3.514 & 12.000 & 558.545 & .000 \\
\hline & $\begin{array}{l}\text { Hotelling's } \\
\text { Trace }\end{array}$ & .207 & 3.620 & 12.000 & 629.000 & .000 \\
\hline & $\begin{array}{l}\text { Roy's } \\
\text { Largest Root }\end{array}$ & .178 & $9.475^{\mathrm{b}}$ & 4.000 & 213.000 & .000 \\
\hline \multirow{4}{*}{$\begin{array}{l}\mathrm{X} 18^{*} \mathrm{X} 21 \\
{ }^{*} \mathrm{X} 17\end{array}$} & Pillai's Trace & .005 & .164 & 6.000 & 424.000 & .986 \\
\hline & $\begin{array}{l}\text { Wilks' } \\
\text { Lambda }\end{array}$ & .995 & $.163^{\mathrm{a}}$ & 6.000 & 422.000 & .986 \\
\hline & $\begin{array}{l}\text { Hotelling's } \\
\text { Trace }\end{array}$ & .005 & .163 & 6.000 & 420.000 & .986 \\
\hline & $\begin{array}{l}\text { Roy's } \\
\text { Largest Root }\end{array}$ & .004 & $.296^{\mathrm{b}}$ & 3.000 & 212.000 & .828 \\
\hline \multicolumn{7}{|c|}{ a. Exact statistic } \\
\hline \multicolumn{7}{|c|}{$\begin{array}{l}\text { b. The statistic is an upper bound on } \mathrm{F} \text { that yields a lower bound on the } \\
\text { significance level. }\end{array}$} \\
\hline \multicolumn{7}{|c|}{$\begin{array}{l}\text { c. Design: Intercept +X18+X21+X17+X18 *X21+X18 *X17+X21 *X17+ } \\
X 18{ }^{*} \mathrm{X} 21{ }^{*} \mathrm{X} 17\end{array}$} \\
\hline
\end{tabular}


Appendix 9. Test of Between-Subjects Effects Destination Brand Association

\begin{tabular}{|c|c|c|c|c|c|c|}
\hline \multicolumn{7}{|c|}{ Tests of Between-Subjects Effects } \\
\hline Source & $\begin{array}{l}\text { Dependent } \\
\text { Variable }\end{array}$ & $\begin{array}{l}\text { Type III } \\
\text { Sum of } \\
\text { Squares }\end{array}$ & df & $\begin{array}{l}\text { Mean } \\
\text { Square }\end{array}$ & $\mathrm{F}$ & Sig. \\
\hline \multirow{3}{*}{$\begin{array}{l}\text { Corrected } \\
\text { Model }\end{array}$} & Y1_FR_KUNJ & $2704.135^{\mathrm{a}}$ & 26 & 104.005 & 1.279 & .174 \\
\hline & Y2_TINGGAL & $13897.851^{\circ}$ & 26 & 534.533 & 1.725 & .020 \\
\hline & Y3_REKOMENR & $4412.722^{c}$ & 26 & 169.720 & 2.747 & .000 \\
\hline \multirow[t]{3}{*}{ Intercept } & Y1_FR_KUNJ & 1643.027 & 1 & 1643.027 & 20.206 & .000 \\
\hline & Y2_TINGGAL & 12567.296 & 1 & 12567.296 & 40.561 & .000 \\
\hline & Y3_REKOMENR & 3587.697 & 1 & 3587.697 & 58.074 & .000 \\
\hline \multirow[t]{3}{*}{$\mathrm{X} 18$} & Y1_FR_KUNJ & 62.090 & 3 & 20.697 & .255 & .858 \\
\hline & Y2_TINGGAL & 211.949 & 3 & 70.650 & .228 & .877 \\
\hline & Y3_REKOMENR & 102.065 & 3 & 34.022 & .551 & .648 \\
\hline \multirow[t]{3}{*}{$\mathrm{X} 21$} & Y1_FR_KUNJ & 1163.482 & 4 & 290.870 & 3.577 & .008 \\
\hline & Y2_TINGGAL & 3774.815 & 4 & 943.704 & 3.046 & .018 \\
\hline & Y3_REKOMENR & 1491.269 & 4 & 372.817 & 6.035 & .000 \\
\hline \multirow[t]{3}{*}{$\mathrm{X} 17$} & Y1_FR_KUNJ & 621.718 & 4 & 155.430 & 1.911 & .110 \\
\hline & Y2_TINGGAL & 1325.330 & 4 & 331.332 & 1.069 & .373 \\
\hline & Y3_REKOMENR & 556.066 & 4 & 139.017 & 2.250 & .065 \\
\hline \multirow[t]{3}{*}{$\mathrm{X} 18 * \mathrm{X} 21$} & Y1_FR_KUNJ & 71.499 & 3 & 23.833 & .293 & .830 \\
\hline & Y2_TINGGAL & 461.676 & 3 & 153.892 & .497 & .685 \\
\hline & Y3_REKOMENR & 112.970 & 3 & 37.657 & .610 & .609 \\
\hline \multirow[t]{3}{*}{$\mathrm{X} 18 * \mathrm{X} 17$} & Y1_FR_KUNJ & 163.337 & 5 & 32.667 & .402 & .847 \\
\hline & Y2_TINGGAL & 544.073 & 5 & 108.815 & .351 & .881 \\
\hline & Y3_REKOMENR & 173.746 & 5 & 34.749 & .562 & .729 \\
\hline \multirow[t]{3}{*}{$\mathrm{X} 21{ }^{*} \mathrm{X} 17$} & Y1_FR_KUNJ & 1906.204 & 4 & 476.551 & 5.861 & .000 \\
\hline & Y2_TINGGAL & 3577.669 & 4 & 894.417 & 2.887 & .023 \\
\hline & Y3_REKOMENR & 1854.996 & 4 & 463.749 & 7.507 & .000 \\
\hline \multirow{3}{*}{$\begin{array}{l}\mathrm{X} 18 \text { * } \mathrm{X} 21 \text { * } \\
\mathrm{X} 17\end{array}$} & Y1_FR_KUNJ & .522 & 2 & .261 & .003 & .997 \\
\hline & Y2_TINGGAL & 260.794 & 2 & 130.397 & .421 & .657 \\
\hline & Y3_REKOMENR & 11.640 & 2 & 5.820 & .094 & .910 \\
\hline \multirow[t]{3}{*}{ Error } & Y1_FR_KUNJ & 17319.798 & 213 & 81.314 & & \\
\hline & Y2_TINGGAL & 65994.482 & 213 & 309.833 & & \\
\hline & Y3_REKOMENR & 13158.611 & 213 & 61.778 & & \\
\hline \multirow[t]{3}{*}{ Total } & Y1_FR_KUNJ & 27240.000 & 240 & & & \\
\hline & Y2_TINGGAL & 158374.000 & 240 & & & \\
\hline & Y3_REKOMENR & 30478.000 & 240 & & & \\
\hline \multirow{3}{*}{$\begin{array}{l}\text { Corrected } \\
\text { Total }\end{array}$} & Y1_FR_KUNJ & 20023.933 & 239 & & & \\
\hline & Y2_TINGGAL & 79892.333 & 239 & & & \\
\hline & Y3_REKOMENR & 17571.333 & 239 & & & \\
\hline \multicolumn{7}{|c|}{ a. R Squared $=.135$ (Adjusted R Squared $=.029$ ) } \\
\hline \multicolumn{7}{|c|}{ b. R Squared $=.174($ Adjusted R Squared $=.073)$} \\
\hline \multicolumn{7}{|c|}{ c. R Squared $=.251$ (Adjusted R Squared $=.160)$} \\
\hline
\end{tabular}

Appendix 10. Multivariate Test of Destination Brand Perceived Quality

\begin{tabular}{|c|c|c|c|c|c|c|}
\hline \multicolumn{7}{|c|}{ Multivariate Tests $^{c}$} \\
\hline \multicolumn{2}{|l|}{ Effect } & Value & $\mathrm{F}$ & $\begin{array}{c}\text { Hypothesis } \\
\mathrm{df}\end{array}$ & Error df & Sig. \\
\hline \multirow[t]{4}{*}{ Intercept } & Pillai's Trace & .185 & $16.264^{\mathrm{a}}$ & 3.000 & 215.000 & .000 \\
\hline & Wilks' Lambda & .815 & $16.264^{\mathrm{a}}$ & 3.000 & 215.000 & .000 \\
\hline & $\begin{array}{l}\text { Hotelling's } \\
\text { Trace }\end{array}$ & .227 & $16.264^{\mathrm{a}}$ & 3.000 & 215.000 & .000 \\
\hline & $\begin{array}{l}\text { Roy's Largest } \\
\text { Root }\end{array}$ & .227 & $16.264^{\mathrm{a}}$ & 3.000 & 215.000 & .000 \\
\hline \multirow[t]{4}{*}{ X32 } & Pillai's Trace & .046 & 1.701 & 6.000 & 432.000 & .119 \\
\hline & Wilks' Lambda & .954 & $1.698^{\mathrm{a}}$ & 6.000 & 430.000 & .120 \\
\hline & $\begin{array}{l}\text { Hotelling's } \\
\text { Trace }\end{array}$ & .047 & 1.694 & 6.000 & 428.000 & .121 \\
\hline & $\begin{array}{l}\text { Roy's Largest } \\
\text { Root }\end{array}$ & .035 & $2.499^{b}$ & 3.000 & 216.000 & .061 \\
\hline \multirow[t]{4}{*}{ X27 } & Pillai's Trace & .052 & 1.273 & 9.000 & 651.000 & 248 \\
\hline & Wilks' Lambda & .948 & 1.283 & 9.000 & 523.404 & 243 \\
\hline & $\begin{array}{l}\text { Hotelling's } \\
\text { Trace }\end{array}$ & .054 & 1.290 & 9.000 & 641.000 & .239 \\
\hline & $\begin{array}{l}\text { Roy's Largest } \\
\text { Root }\end{array}$ & .051 & $3.670^{\mathrm{b}}$ & 3.000 & 217.000 & .013 \\
\hline \multirow[t]{4}{*}{ X37 } & Pillai's Trace & .042 & 1.039 & 9.000 & 651.000 & .407 \\
\hline & Wilks' Lambda & .958 & 1.043 & 9.000 & 523.404 & .404 \\
\hline & $\begin{array}{l}\text { Hotelling's } \\
\text { Trace }\end{array}$ & .044 & 1.045 & 9.000 & 641.000 & .402 \\
\hline & $\begin{array}{l}\text { Roy's Largest } \\
\text { Root }\end{array}$ & .040 & $2.865^{\mathrm{b}}$ & 3.000 & 217.000 & .038 \\
\hline \multirow[t]{4}{*}{ X32 * X27 } & Pillai's Trace & .033 & .810 & 9.000 & 651.000 & .608 \\
\hline & Wilks' Lambda & .967 & .808 & 9.000 & 523.404 & .609 \\
\hline & $\begin{array}{l}\text { Hotelling's } \\
\text { Trace }\end{array}$ & .034 & .806 & 9.000 & 641.000 & .611 \\
\hline & $\begin{array}{l}\text { Roy's Largest } \\
\text { Root }\end{array}$ & .027 & $1.954^{b}$ & 3.000 & 217.000 & .122 \\
\hline \multirow[t]{4}{*}{ X32 * X37 } & Pillai's Trace & .075 & 1.115 & 15.000 & 651.000 & .339 \\
\hline & Wilks' Lambda & .926 & 1.122 & 15.000 & 593.922 & .333 \\
\hline & $\begin{array}{l}\text { Hotelling's } \\
\text { Trace }\end{array}$ & .079 & 1.128 & 15.000 & 641.000 & .327 \\
\hline & $\begin{array}{l}\text { Roy's Largest } \\
\text { Root }\end{array}$ & .064 & $2.799^{b}$ & 5.000 & 217.000 & .018 \\
\hline \multirow[t]{4}{*}{$\mathrm{X} 27^{*} \mathrm{X} 37$} & Pillai's Trace & .027 & .484 & 12.000 & 651.000 & .925 \\
\hline & Wilks' Lambda & .974 & .482 & 12.000 & 569.128 & .926 \\
\hline & $\begin{array}{l}\text { Hotelling's } \\
\text { Trace }\end{array}$ & .027 & .480 & 12.000 & 641.000 & .927 \\
\hline & $\begin{array}{l}\text { Roy's Largest } \\
\text { Root }\end{array}$ & .020 & $1.091^{\mathrm{b}}$ & 4.000 & 217.000 & .362 \\
\hline \multirow{4}{*}{$\begin{array}{l}X 32 * \times 27 * \\
X 37\end{array}$} & Pillai's Trace & .037 & 1.361 & 6.000 & 432.000 & .229 \\
\hline & Wilks' Lambda & .963 & $1.363^{\mathrm{a}}$ & 6.000 & 430.000 & .228 \\
\hline & $\begin{array}{l}\text { Hotelling's } \\
\text { Trace }\end{array}$ & .038 & 1.365 & 6.000 & 428.000 & .227 \\
\hline & $\begin{array}{l}\text { Roy's Largest } \\
\text { Root }\end{array}$ & .035 & $2.487^{\mathrm{b}}$ & 3.000 & 216.000 & .062 \\
\hline \multicolumn{7}{|c|}{ atistic } \\
\hline \multicolumn{7}{|c|}{$\begin{array}{l}\text { b. The statistic is an upper bound on } \mathrm{F} \text { that yields a lower bound on the } \\
\text { significance level. }\end{array}$} \\
\hline \multicolumn{7}{|c|}{$\begin{array}{l}\text { c. Design: Intercept +X32+X27+X37+X32 *X27+X32 *X37+X27 * X37 } \\
+X 32{ }^{*} X 27^{*} X 37\end{array}$} \\
\hline
\end{tabular}


Appendix 11. Test of Between-Subjects Effects Destination Brand Perceived Quality

\begin{tabular}{|c|c|c|c|c|c|c|}
\hline Source & $\begin{array}{l}\text { Dependent } \\
\text { Variable }\end{array}$ & $\begin{array}{l}\text { Type III } \\
\text { Sum of } \\
\text { Squares }\end{array}$ & df & $\begin{array}{l}\text { Mean } \\
\text { Square }\end{array}$ & $\mathrm{F}$ & Sig. \\
\hline \multirow{3}{*}{$\begin{array}{l}\text { Corrected } \\
\text { Model }\end{array}$} & Y1_FR_KUNJ & $1554.833^{\mathrm{a}}$ & 22 & 70.674 & .830 & .686 \\
\hline & Y2_TINGGAL & $7558.422^{\circ}$ & 22 & 343.565 & 1.031 & .428 \\
\hline & Y3_REKOMEND & $787.043^{c}$ & 22 & 35.775 & .463 & .982 \\
\hline \multirow[t]{3}{*}{ Intercept } & Y1_FR_KUNJ & 1239.027 & 1 & 1239.027 & 14.558 & .000 \\
\hline & Y2_TINGGAL & 13604.184 & 1 & 13604.184 & 40.812 & .000 \\
\hline & Y3_REKOMEND & 1086.133 & 1 & 1086.133 & 14.042 & .000 \\
\hline \multirow[t]{3}{*}{ X32 } & Y1_FR_KUNJ & 468.600 & 2 & 234.300 & 2.753 & .066 \\
\hline & Y2_TINGGAL & 408.124 & 2 & 204.062 & .612 & .543 \\
\hline & Y3_REKOMEND & 55.383 & 2 & 27.691 & .358 & .699 \\
\hline \multirow[t]{3}{*}{ X27 } & Y1_FR_KUNJ & 76.669 & 3 & 25.556 & .300 & .825 \\
\hline & Y2_TINGGAL & 2776.085 & 3 & 925.362 & 2.776 & .042 \\
\hline & Y3_REKOMEND & 41.837 & 3 & 13.946 & .180 & .910 \\
\hline \multirow[t]{3}{*}{ X37 } & Y1_FR_KUNJ & 291.468 & 3 & 97.156 & 1.142 & .333 \\
\hline & Y2_TINGGAL & 318.101 & 3 & 106.034 & .318 & .812 \\
\hline & Y3_REKOMEND & 33.141 & 3 & 11.047 & .143 & .934 \\
\hline \multirow[t]{3}{*}{$\mathrm{X} 32{ }^{*} \mathrm{X} 27$} & Y1_FR_KUNJ & 87.230 & 3 & 29.077 & .342 & .795 \\
\hline & Y2_TINGGAL & 1023.180 & 3 & 341.060 & 1.023 & .383 \\
\hline & Y3_REKOMEND & 184.348 & 3 & 61.449 & .794 & .498 \\
\hline \multirow[t]{3}{*}{$\mathrm{X} 322^{*} \mathrm{X} 37$} & Y1_FR_KUNJ & 945.977 & 5 & 189.195 & 2.223 & .053 \\
\hline & Y2_TINGGAL & 674.675 & 5 & 134.935 & .405 & .845 \\
\hline & Y3_REKOMEND & 145.785 & 5 & 29.157 & .377 & .864 \\
\hline \multirow[t]{3}{*}{$\mathrm{X} 27^{*} \mathrm{X} 37$} & Y1_FR_KUNJ & 33.446 & 4 & 8.362 & .098 & .983 \\
\hline & Y2_TINGGAL & 389.822 & 4 & 97.456 & .292 & .883 \\
\hline & Y3_REKOMEND & 152.510 & 4 & 38.128 & .493 & .741 \\
\hline \multirow{3}{*}{$\begin{array}{l}X 32{ }^{*} \mathrm{X} 27^{*} \\
\mathrm{X} 37\end{array}$} & Y1_FR_KUNJ & 124.753 & 2 & 62.377 & .733 & .482 \\
\hline & Y2_TINGGAL & 2295.608 & 2 & 1147.804 & 3.443 & .034 \\
\hline & Y3_REKOMEND & 174.783 & 2 & 87.391 & 1.130 & .325 \\
\hline \multirow[t]{3}{*}{ Error } & Y1_FR_KUNJ & 18469.100 & 217 & 85.111 & & \\
\hline & Y2_TINGGAL & 72333.911 & 217 & 333.336 & & \\
\hline & Y3_REKOMEND & 16784.291 & 217 & 77.347 & & \\
\hline \multirow[t]{3}{*}{ Total } & Y1_FR_KUNJ & 27240.000 & 240 & & & \\
\hline & Y2_TINGGAL & 158374.000 & 240 & & & \\
\hline & Y3_REKOMEND & 30478.000 & 240 & & & \\
\hline \multirow{3}{*}{$\begin{array}{l}\text { Corrected } \\
\text { Total }\end{array}$} & Y1_FR_KUNJ & 20023.933 & 239 & & & \\
\hline & Y2_TINGGAL & 79892.333 & 239 & & & \\
\hline & Y3_REKOMEND & 17571.333 & 239 & & & \\
\hline \multicolumn{7}{|c|}{ a. R Squared $=.078$ (Adjusted R Squared $=-.016$ ) } \\
\hline \multicolumn{7}{|c|}{ b. R Squared $=.095$ (Adjusted R Squared $=.003)$} \\
\hline \multicolumn{7}{|c|}{ c. $R$ Squared $=.045$ (Adjusted R Squared $=-.052$ ) } \\
\hline
\end{tabular}

